\title{
The determinants of inward foreign direct investment: Evidence from the European regions
}

\author{
José Villaverde ${ }^{\mathrm{a}, \mathrm{b}}$, Adolfo Maza ${ }^{\mathrm{a}}$ \\ ${ }^{a}$ University of Cantabria, Department of Economics, Santander, Spain. \\ ${ }^{\mathrm{b}}$ University of Limerick, Kemmy Business School, Limerick, Ireland.
}

\begin{abstract}
The aim of this paper is to study the determinants of FDI in the 260 EU NUTS2 regions between 2000 and 2006. After reviewing the relevant literature and the major traits of the FDI regional distribution in the EU, we analyse its drivers. First, we specify the model and perform a factor analysis to reduce the vast number of potential determinants to a manageable size. Afterwards, we estimate a reduced version of the model with the extracted factors as independent variables. We find that economic potential, labour market characteristics, technological progress and competitiveness exert a significant impact on FDI location patterns; in contrast, market size and labour regulation do not seem to play any noteworthy role. Finally, we perform some robustness tests to make sure the results are not sensitive to outliers, spatial dependence, size of regions, endogeneity and the consideration of just the top 50 FDI recipient regions.
\end{abstract}

Keywords: Foreign direct investment; factor analysis; European regions.

\footnotetext{
* We would like to thank the Swedish Institute for European Policy Studies (SIEPS) for financial support, W. Polasek and R. Sellner for providing us with the FDI regional database, and two anonymous referees for their helpful comments and suggestions. We also benefited from the comments of participants in a seminar held at SIEPS (Stockholm, January 2013) and in the XV World Economic Meeting (Santander, June 2013).

- Corresponding author at: Department of Economics, University of Cantabria, Avda. Los Castros, s/n, 39005, Santander (Spain)

Telephone: +34942201652; Fax: +34942201603.

Email address: mazaaj@unican.es; adolfo.maza@unican.es
} 


\section{Introduction}

In recent decades, and particularly since mid-1990s, one of the most striking developments in the global economy has been the remarkable growth of foreign direct investment (FDI). ${ }^{1}$ As a result, FDI has become a key component of the economic strategies put forward by most developed and developing countries. Although there may be various reasons behind such behaviour, this is most likely related to the fact that FDI is generally considered to be a major factor in enhancing economic growth (e.g., Lim, 2001; Caves, 2007; Dunning and Lundan, 2008; Franco, 2013).

Europe, and more specifically the European Union (EU), has traditionally been one of the main recipients of FDI, particularly since the launching of the single market program, the introduction of the euro, and the last two enlargements. Therefore, the study of FDI in the EU is, especially from a policy-oriented point of view, of paramount interest. Numerous papers have analysed this issue (for a review, see, among others, Barba and Venables, 2004), but most have been performed either at a national level or for sets of regions of just a single EU country. This national focus (or, at best, narrow regional focus) is mostly due to a lack of homogeneous statistical information on FDI for all the EU regions.

Because of these data problems, several authors and institutions have attempted to circumvent them by producing their own statistics, among which the well-known

\footnotetext{
${ }^{1}$ According to OECD data, FDI inflows in the world increased more than eight-fold between 1990 and 2011, from $\$ 203,772$ to $\$ 1,660,558$ million.
} 
FDIRegio and Elios databases. Although very interesting, these two databases - both of which offer directly observed regional data - suffer from a critical drawback: they provide regional information just about the number of foreign firms with affiliates in EU countries, but they fail to offer any information on the actual amounts of money invested by these companies. ${ }^{2}$ For this reason, this paper makes use of a different, novel FDI regional database built, from national data, with the spatial Chow-Lin data interpolation method (Polasek and Sellner, 2010; and Polasek et al., 2010). ${ }^{3}$ Although this database has also some limitations - e.g., it does not include any sectoral breakdown or the country of FDI origin-, in our opinion it is superior to the FDIRegio and Elios databases because it does offer information about the total amount of FDI in the EU regions.

Bearing all these considerations in mind, this paper attempts to contribute to the literature on inward FDI determinants in four different and simultaneous aspects. First, it uses data on all EU regions, as in this way the results obtained are more general than

\footnotetext{
2 The FDIRegio database is obtained from the Amadeus database compiled by the Bureau Van Dijk. For each company, this database provides information about the year of incorporation, country/region of origin and destination, ownership structure, and sector of activity, among other data. The Elios (European Linkages and Ownership Structure) database, built at the University of Urbino (Italy), collects information from Dun \& Brasdstreet's Who owns whom for the five largest European countries. For each firm, the database supplies the name/country of the ultimate owner, sector of activity, location, and year of establishment.

${ }^{3}$ As indicated by Polasek and Sellner (2011, p. 25) "the spatial Chow-Lin procedure uses the relationship between a dependent variable that is only measured at a more aggregate regional level (...) and independent variables that are measured at a more disaggregate regional level (...) to predict the dependent variable at the disaggregate regional level”.
} 
those coming from samples made up of just a specific group of regions; our sample comprises 260 NUTS2 regions and, for reasons of data availability, goes from 2000 to 2006. ${ }^{4}$ Second, it uses data on the real amount of FDI received by each region rather than on the number of affiliates of foreign firms; this is one of the main drawbacks of previous papers on this topic. Third, an additional contribution of the paper rests on the way of selecting potential FDI determinants; in contrast to the more usual, ad hoc selection of variables, it employs exploratory factor analysis because this is an advisable statistical tool to simplify econometric analysis when the number of potentially explanatory variables in a model is, as in this case, very large; the results obtained are supported by appropriate theories well established in the literature. Fourth, we provide an extensive robustness checking, including results obtained after controlling for spatial dependence, the presence of outliers, endogeneity, and so on; this is an additional point of the paper because, apart from reinforcing its main results, allows us to gain additional insights.

The rest of the paper is organised as follows. In Section 2 we briefly review the theoretical literature on the main inward FDI determinants, and offer a survey of empirical studies for the EU regions. Then, to offer some insights about the specifics of our case study, Section 3 outlines the pattern of the regional distribution of inward FDI

\footnotetext{
${ }^{4}$ NUTS stands for Nomenclature of Units for Territorial Statistics. In this paper, we use the NUTS2 definition from 2003, such that Denmark is considered as one region. Although we are well aware that this administrative delimitation of regions could mask some key aspects of the EU economic reality, we have adopted it because it is officially used by the EU and, in addition, it is the only one for which homogeneous data on potential FDI determinants exist. For further reference on this issue, see Maza and Villaverde (2011).
} 
in the EU. In Section 4, which constitutes the central part of the paper, we pursue four tasks: we specify the model to be estimated; we perform a factor analysis to reduce the huge number of potential FDI determinants reported by the literature to a manageable size; we estimate the model and discuss its results; and we carry out a set of robustness checks addressing five main issues: a) potential outliers; b) spatial dependence; c) different size of regions, d) endogeneity, and e) the consideration of only the top 50 FDI receiving regions. Section 5 presents the main conclusions.

\section{FDI determinants: A review}

\subsection{A brief theoretical survey on FDI determinants}

Because this is eminently an empirical paper, a complete summary of the FDI theory is clearly beyond its scope. In any case, it is convenient to note that, although the potential determinants of FDI have been studied extensively, no general theory has been accepted yet. As a short reference it is worthy of mention the existence of very good surveys on the issue, among which those of Blonigen (2005) and Faeth (2009) are some of the most relevant.

Drawing on Faeth's (2009) paper, the first attempts to explain FDI were proposed in the context of neoclassical trade models by MacDougall (1960) and Kemp (1964). In a nutshell, the explanation offered by these authors lies in the differences in return to capital in favour of FDI. According to Kindleberger (1969), however, FDI cannot exist in a world of perfect competition. Following on this reasoning, Hymer (1976) 
developed a theory of market imperfection that explains FDI by ownership advantages in the form, for instance, of product differentiation, internal or external economies of scale, and government incentives. Caves (1971) and Knickerbocker (1973) employed a similar approach, with the former focusing on product differentiation and the latter on oligopoly rivalry. Considering the issue of firm rivalry, Vernon (1966) developed his theory of the product life cycle, according to which there is a cost-based rationale for firms changing from exporting to foreign-based production (FDI) because the products they manufacture move from one to another of the three (new, mature, standardised) stages of their life cycle. Internalisation theory (Buckley and Casson, 1976) explains FDI as an application to multinational enterprises (MNEs) of the idea of internalising transactions in response to market failures.

The aforementioned approaches were, to a certain extent, summarised and made consistent in the so-called OLI eclectic paradigm developed by Dunning $(1977,1979)$. According to Dunning, FDI can be explained "by identifying three types of special advantages that MNEs possess: ownership (O), location (L) and internalization (I) advantages” (Faeth, 2009, p. 171). Because we are interested in explaining the geographical distribution of inward FDI in the EU regions, here the advantages of location are of paramount importance. ${ }^{5}$ These location advantages are usually divided into three types: economic, political, and sociocultural advantages. Table 1, taken from UNCTAD (1999), includes what we consider to be the best synthesis of the location advantages (host country determinants of FDI). Focusing our comments on the

\footnotetext{
${ }^{5}$ The other two advantages (ownership and internalisation) are firm-specific and considered as exogenous variables from the perspective of the host country.
} 
economic determinants, it can be observed that they can be broken down into three groups: market-seeking, resource/asset-seeking, and efficiency-seeking determinants.

(Table 1 around here)

In addition to these approaches, the new theory of international trade and the so-called institutional approach also provide explanations for FDI. Building on the OLI paradigm, in the new theory of international trade FDI is linked to variables such as market size, barriers to entry, transport costs, and factor endowments. In the institutional approach "FDI can be seen as a game with two players, MNE and host government, or a contest between two or more host countries competing for FDI” (Faeth, 2009, p. 183). Variables such as financial incentives, fiscal incentives, and other economic incentives play a crucial role in explaining FDI in this approach.

\subsection{A brief empirical survey on FDI determinants in the EU regions}

Although the theoretical literature on FDI determinants is very rich, the empirical one about the EU regions is relatively scarce. Even so, it is possible to distinguish among three types of studies: those of regions in a single EU country, of regions within a group of EU countries, and of regions in all EU countries. 
The first group is the most densely populated but, nevertheless, not very abundant. ${ }^{6}$ Generally speaking, these studies (in particular the papers by Fallon and Cook, 2010, on UK regions, and Villaverde and Maza, 2012, on Spanish regions) provide evidence that market-seeking, resource/asset-seeking, and efficiency-seeking factors do emerge as the main determinants of FDI. It is important to stress, however, that the relative influence of these factors to attract FDI differs notably among the papers belonging to this group.

In view of the scope of this paper, we are mostly interested in the second and third types of studies, which, as mentioned in the Introduction, only employ information on the number of foreign firms establishing affiliates in the European regions. There are not many papers devoted to the analysis of FDI for regions belonging to a group of a few countries, among which those by Basile et al. $(2008,2009)$ offer, in our opinion, the most interesting insights. Both papers employ similar estimation techniques (a mixed logit model and a nested logit model, respectively) and achieve similar findings. They conclude that factors such as market size and market potential, agglomeration, labour conditions, $\mathrm{R}+\mathrm{D}$ investment play, among others, an important role in attracting FDI. Additionally, these papers also draw two important conclusions from the point of view of our analysis in Section 4. The first paper concludes that "regions within countries that were eligible for the CF (Cohesion Fund) are significantly more attractive than other regions” (Basile et al., 2008, p. 336), in particular for European MNEs. The second paper (Basile et al., 2009) suggests that, as the EU is perceived to be a rather well-

\footnotetext{
${ }^{6}$ Main references are Crozet et al. (2004), Fazekas (2005), Pelegrin and Bolancé (2008), Chidlow et al. (2009), Majocchi and Presutti (2009), Papalia and Bertarelli (2009), Pazienza and Vecchione (2009), Cook (2010), Fallon and Cook (2010), Castiglione et al. (2012), Villaverde and Maza (2012) and Wren and Jones (2012).
} 
integrated area, country boundaries do not matter too much for the location choice of MNEs, especially, once again, European MNEs.

The third group of studies, considering the regions of all EU countries, is even more sparsely populated than the previous ones. This last group includes, to the best of our knowledge, only two papers (Casi and Resmini, 2010; and Capello et al., 2011). The first one, starting with standard OLS techniques and then controlling for spatial dependence, estimates various specifications of the FDI equation including as FDI determinants those traditionally suggested by the literature (e.g. market potential, GDP growth, labour costs, human capital, agglomeration, among others). Once again, and mainly with relation to European MNEs, the conclusions obtained are basically in line with the theoretical predictions in that the aforementioned variables do emerge as key drivers of FDI regional location. Another important conclusion is that location patterns somewhat differ between European and non-European MNEs. In particular, location patterns of European MNEs are affected by spatial autocorrelation - this fact suggesting that the proximity to FDI receiving regions is also important in explaining them-, whereas this is not the case for non-European MNEs.

The Capello et al. (2011) paper follows roughly the same pattern as Casi and Resmini (2010) in that it considers a set of conventional FDI determinants (market potential labour costs, industrial mix, human capital, among others), but it adds different forms of spatial heterogeneity. Among its conclusions, the most relevant is that agglomeration and human capital are key factors in explaining FDI location, whereas, contrary to what theory predicts, labour costs are non-significant and market access is only marginally 
significant. Finally, an important outcome in both papers is that the capacity of a region to attract FDI varies, sometimes markedly, with sector specificities. The paper finds specifically that location externalities arise in (low-tech) manufacturing and service sectors.

\section{EU inward FDI flows: A regional perspective}

As the starting point for our empirical analysis, this section furnishes an overview of the regional distribution of inward FDI flows in the EU for the period 2000-2006, using the database provided by Polasek and Sellner. This database provides information about the amount of inward FDI stocks at a regional level in current million euros. In this paper, FDI flows are computed as the difference between consecutive inward FDI stocks, and the data are transformed from nominal into real terms (considering 2000 as the base year) by using national deflators.

The EU is one of the largest recipients of FDI in the world. According to the European Union foreign direct investment Yearbook 2008 (EUROSTAT, 2008), the share of EU FDI inflows (excluding intra-EU flows) in worldwide FDI flows was around $20 \%$ in

2006. In contrast, the USA presented a share of 18\%. If FDI flows between EU countries were also computed, the European share would be more than double.

From the point of view of the regional distribution of inward FDI in the EU, Table 2 offers information about the average levels over the whole period. For the sake of simplicity, due to the large number of regions in the sample, the table only shows the 
top 10 and bottom 10 regions. As can be observed, the position of Île de France clearly stands out. This region receives 35.5 billion euros annually, well above three times more than the second region in the ranking (Brussels). All of the regions in the top 10 belong to the EU15. Conversely, 9 out of the 10 regions with the worse performance are Greek regions.

Table 2 yields the impression that inward FDI is highly concentrated from a regional perspective. To present this result in a more precise manner, Table 3 reports the levels of inward FDI regional concentration. For the whole period, more than $30 \%$ of the total inward FDI is located in just 10 regions. Additionally, it is shown that the top 30 regions concentrate $52 \%$ of the total inward FDI, whereas the top 50 regions concentrate more than 64\%. Regarding yearly data the most remarkable fact is the increase in concentration that took place in 2002 due to disinvestment. ${ }^{7}$

(Table 2 around here)

(Table 3 around here)

Although informative, these concentration ratios fail to offer any relevant clue about the relative FDI performance and attractiveness of the regions. To address this issue, UNCTAD (2001) proposed the use of two indicators: the FDI Performance Index and the FDI Potential Index. The Performance Index compares the shares of inward FDI to

\footnotetext{
${ }^{7}$ As a referee pointed out and in line with Park (2000), a conjecture to explain not only the results for 2002 but also the general evolution of FDI is that it tends to be located in areas with low wages and, once their attractiveness dissipates as wage inflation occurs, FDI moves to high wage areas. However, this is not our case as most of the disinvestment occurred in UK regions.
} 
GDP, ${ }^{8}$ whereas the Potential Index attempts to grasp the region's attractiveness to foreign investors by using more scaling variables than just the GDP. Specifically, in the computation of the Potential Index we employ the following scaling variables: per capita GDP, R\&D expenditures as percentage of GDP, exports plus imports as percentage of GDP, and the percentage of employment in high technology sectors. Information about these two indices for the average of the sample period is reported in the first two columns of Table A.1 (in the Appendix).

For the sake of simplicity and following UNCTAD's recommendation in its World Investment Report, 2002, we consider "useful to compare the rankings based on the two indices as a rough guide to whether countries are performing adequately given their (restricted set of) structural assets" (UNCTAD, 2002, p. 29). The combination of the two inward FDI indices yields a $2 * 2$ matrix, according to which host regions may be considered as front-runners (high potential and high performance), above-potential economies (low potential and high performance), below-potential economies (high potential and low performance), or under-performers (low potential and low performance) ${ }^{9}$

The results of this grouping are disclosed in the third column of Table A.1 (in the Appendix) and graphically presented in Map 1. As can be observed 49 front-runner regions arise, most of which are located in Belgium, the Netherlands, Sweden, and the

\footnotetext{
${ }^{8}$ In the literature, it is also very common to use the FDI/Population ratio along with the FDI/GDP ratio. However, because the coefficient of correlation between these two ratios is rather high (more than 0.8), in this paper we just employ the FDI/GDP ratio.

${ }^{9}$ The dividing value is always the (population) weighted average of each index.
} 
UK. A similarly sized group of above-potential regions (46) exists, highlighting the presence of a high number of Spanish and Polish regions; in other words, for this regions it should be expected a decrease of FDI inflows in the near future. The belowpotential label may be assigned to 64 regions, including German (20), French (6), and British (10) regions; these regions might receive additional FDI inflows in the future if MNEs eventually discover their opportunities and exploit them. Finally, the remaining 101 regions form the group of under-performers, a group with a remarkable number of regions belonging to the new EU Member States, but also regions in Germany (16), Spain (10), France (11), Italy (17), and the UK (11). Not surprisingly, most of the Greek regions also belong to this group.

(Map 1 around here)

The analysis conducted to this point has overlooked an important issue. It has not paid any attention to the likely existence of spatial dependence in the regional distribution of FDI. In other words, it has not considered the role potentially played by the geographic situation of each region. Consistent with assumptions and predictions based on openeconomy endogenous growth models (see, for example, the books by Grossman and Helpman, 1992; and Barro and Sala-i-Martin, 2003) and new economic geographic theory (see the survey by Ottaviano and Puga, 1998), it seems logical that a certain spatial dependence exists —i.e., we may expect regions with higher (lower) FDI inflows to be geographically closer to (further from) each other. To address this important issue, we develop an exploratory spatial analysis by computing the so-called Moran's I 
statistic that measures the spatial dependence across our geographical entities. This statistic is defined as follows (Anselin, 1988):

$$
I=\frac{n}{\sum_{i} \sum_{j} w_{i j}} \frac{\sum_{i} \sum_{j} w_{i j}\left[f d i_{i}-\mu\right]\left[f d i_{j}-\mu\right]}{\sum_{i}\left[f d i_{i}-\mu\right]^{2}}
$$

where $f d i_{i}$ and $f d i_{j}$ are, in this case, FDI/GDP ratios of regions $i$ and $j ; \mu$ is the European average; $w_{i j}$ is an element of the distance matrix $W$ between each pair of regions; $\sum_{i} \sum_{j} w_{i j}$ is a standardisation factor that corresponds to the sum of all the weights; and $n$ is the number of regions. In order to facilitate the interpretation of the statistic, the standardised value (z-value) is obtained. Accordingly, a significant positive (negative) value for the Moran's I statistic will imply positive (negative) spatial association. The results obtained, using the inverse of the standardised distance as a distance matrix, confirm the existence of a positive spatial autocorrelation in all of the sample years (except 2003) and the whole period (Table 4). Although the table also reveals that the degree of spatial dependence varies over time, the results clearly prove that the European regions tend to be concentrated around rather similar levels of inward FDI/GDP ratios.

(Table 4 around here)

\section{Inward FDI determinants in the EU regions: An empirical analysis}


Due to the scarcity of literature about the determinants of inward FDI flows among EU regions, this section attempts to add to it by simultaneously focussing on the three points mentioned in the Introduction: the consideration of all EU regions, the use of data on the real amount on FDI received by each region; and the use of factor analysis as a data reduction tool to organise the large number of potential FDI drivers into useful and uncorrelated aggregates. To accomplish this aim we operate in four stages. First, we specify our baseline model and discuss data. Second, we develop an exploratory factor analysis. Third, we estimate the model and discuss the results. Fourth, we verify the robustness of the results.

\section{1. $\quad$ The model and data}

In order to assess the main determinants of inward FDI in the EU at regional level, here we specify our baseline model, in which the endogenous variable ( $\left.f d i_{i}\right)$ is defined, as previously mentioned, as the FDI/GDP ratio for region $i$. With regard to the explanatory variables, we draw on the large number of them proposed in the theoretical and empirical literature, basically those related to the economic characteristics of our sample of regions.

In any case, regarding model specification it is necessary to point out some data problems crucially affecting it. First, that inward FDI flows change significantly between years, due mainly to large fluctuations in mergers and acquisitions; second, that there are many missing observations on some potential determinants of inward FDI. Therefore, hereafter we decide to only pay attention to the whole period 2000-2006 and, 
consequently, take average values both for inward FDI flows and for all of the variables that theoretically are behind them. ${ }^{10}$

The existence of omitted data points for certain regions is not, however, the worst situation, because data on some potential FDI drivers are totally unavailable for some regions over the whole sample period. In this case we proceed as follows: if there are no data for a large number of regions (more than 5\% of the 260 regions in the sample), we completely remove these variables from our analysis; if data are unavailable for less than $5 \%$ of the regions, we do the following:

1. If NUTS1 data are available, we assign them to NUTS2 regions.

2. If NUTS1 data are unavailable but country data are available, we assign them to NUTS2 regions.

3. If neither NUTS1 nor country data are available, we proceed in three steps. First, we identify regions with a similar per capita GDP; second, for these regions, we calculate the corresponding "variable/GDP” average ratio; third, we assign to the region for which we have no data a value equal to the product of its GDP times the aforementioned ratio.

All in all, our final dataset of FDI determinants consists of a total of 21 variables. Table 5 includes the definitions, acronyms, units of measurement, data sources and available years for all of them. Table 6 reports summary statistics for each variable. Consequently, our baseline regression model is specified, for each region $i$, as follows:

\footnotetext{
${ }^{10}$ For variables with omitted data points, we compute mean values for just the available data
} 
$f d i_{i}=\alpha+\sum_{k=1}^{21} \beta_{k} Z_{k i}+\varepsilon_{i}$

where $Z_{k i}$ represents the $k$-th explanatory variable in region $i$.

(Table 5 around here)

(Table 6 around here)

\subsection{Factor analysis}

As it is well known, working with such a large number of inward FDI drivers (21) would be difficult and could cause several problems in the regression analysis due to the presence of multicollinearity among them. To overcome this problem, we carry out a standard exploratory factor analysis, using the approach described by Nardo et al. (2005). ${ }^{11}$

11 Although we are well aware of the limitations of factor analysis (it somewhat obscures the true determinants of inward FDI), it is very convenient for reducing multicollinearity between explanatory variables. A pioneering study employing factor analysis to the study of FDI determinants is Ajami and Ricks (1981). Recently a few papers have also applied this methodology to the study of FDI, among which Boermans et al. (2011), Villaverde and Maza (2012) and Bartels et al. (2013) stand out. 
By applying this approach and Kaiser's criterion for factor extraction, ${ }^{12}$ we identify six factors with eigenvalues greater than 1 (Table 7), which explain $81.0 \%$ of the cumulative variance of the 21 original variables. The composition of these six factors is reported in Table 8. The first factor $\left(\mathrm{F}_{1}\right)$ includes labour productivity, per capita GDP, wages, air and multimodal accessibility, and market potential, thus we tentatively label it as economic potential. The second factor $\left(\mathrm{F}_{2}\right)$, named market size, comprises GDP, population, and investment variables. The third factor $\left(\mathrm{F}_{3}\right)$, local labour market characteristics, includes the employment rate, activity rate, inverse of unemployment rate, and inverse of long-term unemployment rate. The fourth factor $\left(\mathrm{F}_{4}\right)$, technological progress, contains four indicators: R\&D investment, R\&D personnel, high technology sector, and human capital. The fifth factor $\left(\mathrm{F}_{5}\right)$, labour regulation, encompasses labour market regulation and the inverse of labour law rigidity and tax wedge measured at national level. Finally, the sixth factor $\left(\mathrm{F}_{6}\right)$, which we dub as competitiveness, combines openness degree (exports+imports over GDP) and manufacturing share.

(Table 7 around here)

(Table 8 around here)

Apart from the empirical rationale, the theoretical rationale for the composition of each one these factors should be obvious, as all of them are, directly or indirectly, wellgrounded on the FDI determinants theory summarised in Section 2.1, as well as on the theories of economic growth and the new economic geography (NEG). Perhaps the

\footnotetext{
12 The Kaiser-Meyer-Olkin measure of sampling adequacy and Bartlett's test of sphericity indicate that our sample is adequate to conduct an exploratory factor analysis. The results are available upon request.
} 
most debatable issue revolves around the inclusion of air and multimodal accessibility (MULA) and market access in F1. As is well known, MULA is an indicator of transport infrastructure and, as the economic theory explains, infrastructure is a key ingredient for the promotion of growth. ${ }^{13}$ In the same vein, NEG models (for a good survey see Redding, 2011) support positive correlation between GDP per capita, productivity and wages on one side, and MULA and market access on the other. In fact, the so-called wage equation of the NEG predicts that regional income is a positive function of the regional access to the main international markets. ${ }^{14}$

After having extracted these factors and to use them in our regression analysis, it is required to create scores to represent each region's placement on each factor. There are several approaches to compute factor scores (DiStefano et al., 2009) and in this paper, for the sake of robustness, we employ two alternative ones: the so-called 'sum scores' and 'regression scores' approaches.

\subsection{Estimation of the model}

This subsection appraises the main determinants of inward FDI in the EU at regional level. To do that we adopt the baseline model but, due to the econometric problems

\footnotetext{
${ }^{13}$ This idea has been empirically implemented by the EU in its Territorial Agenda (2007, p. 6), in which is stated that "mobility and accessibility are key prerequisites for economic development of all regions of the EU”.

${ }^{14}$ A recurring concept in the literature discussing this topic is the term 'curse of distance', defined as the tendency of peripheral regions to have lower income and wages because of being far from the main markets (for a recent empirical work on this issue see López-Rodríguez et al., 2011).
} 
mentioned above, we take advantage of the factor analysis in order to estimate a reduced version of it. To be precise, we modify equation (2) by considering the previously extracted factors (in both the 'sum scores' and 'regression scores' approaches) as independent variables plus, according to Basile et al. (2008), an additional dummy variable capturing regions belonging to a country eligible for the Cohesion Fund $(C F) .{ }^{15}$ Therefore, we estimate the following reduced cross-section equation:

$$
f d i_{i}=\alpha+\beta_{1} F_{1 i}+\beta_{2} F_{2 i}+\beta_{3} F_{3 i}+\beta_{4} F_{4 i}+\beta_{5} F_{5 i}+\beta_{6} F_{6 i}+\beta_{7} C F_{i}+\varepsilon_{i}
$$

The estimation is initially run by standard (OLS) regression techniques. As can be observed (Table 9), the results obtained with 'sum scores' and 'regression scores' approaches are very similar. These results reveal that $f d i$ is, as expected, positively and significantly correlated to the economic potential, labour market characteristics, technological progress, and competitiveness of the regions. The coefficient linked to $C F$ is also positive and significant; hence being a region of a Cohesion country has to be considered as another attraction factor for FDI.

(Table 9 around here)

Although economic analysis suggests market size and labour regulation factors are also potential determinants of FDI, our findings indicate that their coefficients are

\footnotetext{
${ }^{15}$ We also included a dummy for the Objective 1 regions, but it turned out to be statistically nonsignificant.
} 
statistically non-significant at conventional levels. A tentative explanation for the negligible impact of market size may be that the dimension of the local (i.e., regional) market in which the investment effectively occurs is of no great relevance, given the high degree of European integration. This explanation is consistent with Basile et al.'s finding that "European multinationals consider regions across different countries as relatively closer substitutes than regions within national borders” (Basile et al., 2009, p. 733). With reference to labour regulation, our results support the idea that MNEs do not pay any heed to regional labour market regulations but to the regional employment/unemployment situation (recall that labour market characteristics emerged as a relevant factor) when it comes to investing in the EU.

\subsection{Robustness checks ${ }^{16}$}

The aim of this subsection is to deal with the issue of robustness. We consider this analysis to be very pertinent in all empirical studies and especially when, as in this case, the explanatory power of the model is relatively weak (low R-square). In particular we perform five independent robustness checks: first, to assess whether previous results are conditioned by the presence of outliers; second, to consider the existence and influence of spatial dependence; third, to evaluate the potential impact of the different size of the regions included in the sample; fourth, to evaluate the problem of endogeneity bias, and fifth, to discern whether the results are confirmed when the number of regions in the

\footnotetext{
${ }^{16}$ Because of their similarity, in this subsection we only report the results for the estimation with ‘regression scores’. The results with ‘sum scores’ are available upon request.
} 
sample is much lower than the initial one and only includes those receiving the most FDI flows.

\subsubsection{Presence of outliers}

Up to now the regression analysis has considered the full sample of 260 regions. However, there seem to be several outliers especially located at the upper tail of the fdi distribution (see Figure 1). Because the presence of these outliers could affect the regression results, we re-estimate Equation (3) by means of two alternative methods: first, by removing outliers from the sample, ${ }^{17}$ and second by applying quantile (mean) regression techniques. The first two columns of Table 10 report the results. As observed, in both cases they are roughly the same as before, therefore we are able to assert that the presence of outliers does not significantly affect our findings. Consequently, it seems that the initial results are robust.

(Table 10 around here)

\subsubsection{Spatial dependence}

Another important point is that, as mentioned, we have carried out the estimation of Equation (3) by using standard OLS econometric techniques. At the end of Section 3,

${ }^{17}$ As it is usual, to identify outliers we proceed as follows (see the seminal papers by Tukey, 1977; and Frigge et al., 1989): denoting by Q the quartiles of the distribution, the outliers refer to those regions with an fdi value below Q1 - 1.5*(Q3-Q1) and above Q3 + 1.5*(Q3-Q1). As a result of using these two expressions we identify 21 outliers, representing $8 \%$ of the initial sample. 
however, we made a passing reference to the presence of some spatial dependence across European regions in terms of FDI inflows. Accordingly, it seems that a spatial analysis is pertinent to gain a more precise understanding of the regional situation of inward FDI in the EU. In other words, it appears that the location patterns of MNEs may be influenced by the spatial distribution of inward FDI. There is indeed no doubt in the literature about the fact that factors determining FDI may well span beyond regional boundaries. Considering this, it is necessary to revise the regression analysis to eschew potential inconsistencies and inefficiencies in the results of the estimated equation (Anselin, 1988; Anselin and Bera, 1998). With this aim, we conduct a series of Lagrange multipliers (LM) tests based on the principle of maximum likelihood. ${ }^{18}$ Specifically, the LM-ERR test, along with the associated robust LM-EL test, check for the absence of residual spatial autocorrelation, which would be caused by not including a structure of spatial dependence in the error term. The LM-LAG test, along with the associated robust LM-LE test, check for the absence of substantive spatial autocorrelation, which would be caused by the presence of spatial autocorrelation in the endogenous variable.

We apply these tests to Equation (3). Table 11 reveals that the result for the LM-LAG test (41.6) is greater than that of the LM-ERR test (31.5). Therefore, it seems that we should re-estimate the model by including the spatial lag of the dependent variable as an additional explanatory variable. This conclusion is confirmed if we look at the

\footnotetext{
${ }^{18}$ Tests that require the normality assumption in the residuals to be satisfied. In this respect, the results obtained from the Bera-Jarque test are satisfactory.
} 
associated robust test results; LM-LE remains significant at 1\%, whereas LM-EL loses all significance.

(Table 11 around here)

These results indicate that we should correct the substantive spatial dependence in our model. Therefore, we adjust it to also include as exogenous variable a spatial lag of regional inward $f d i\left(W_{-} f d i_{i}\right)$, being $W$ the same distance matrix — with elements $w_{i, j}$ reflecting the intensity of the interdependence between regions $i$ and $j$ - employed to compute the Moran's I statistic. This new variable intends to capture the relationship between the FDI flows towards a region and those of its neighbours.

The third column of Table 10 displays the results obtained when Equation (3) includes the spatial lag and is estimated by maximum likelihood. ${ }^{19}$ Three points should be highlighted. First, all of the goodness of fit measures that are comparable between the reduced model (Table 9) and the new spatial model, such as the logarithm of maximum likelihood (LIK), Akaike's Information Criterion (AIC), and Schwartz's Criterion (SC), ${ }^{20}$ demonstrate that the spatial model achieves a better fit. Second, with respect to the influence of the extracted factors, the results are equivalent to those previously obtained, which confirms their robustness. Finally, the coefficient linked to the spatial

\footnotetext{
${ }^{19}$ Spatial dependence invalidates the traditional OLS estimation method. It is also important to point out that, according to our tests, there are no problems of heteroskedasticity in this model.

${ }^{20} \mathrm{R}^{2}$ is not an appropriate measure to compare them because it does not have the same meaning in the two cases due to the inclusion of spatial lag variables.
} 
lag of regional inward $f d i$ is positive and statistically significant, confirming the results of the earlier spatial dependence tests, i.e., that the behaviour of each region is closely related to the behaviour of its neighbouring regions. To a certain extent, this result could be considered, as literature suggests, as a sign that agglomeration is an important factor in determining inward FDI.

\subsubsection{Weighted regression model}

We also want to ensure whether the rather different size of the regions considered in our analysis could be affecting the results obtained. To accomplish this aim we have reestimated Equation (3) by WLS, using employment data as weights. ${ }^{21}$ By doing this, we intend to reduce the degree of heterogeneity across regions.

The results displayed in the fourth column of Table 10, apart from reinforcing previous findings, reveal that the main difference with those obtained for the reduced model lies precisely on the coefficient linked to the market size factor. Now, it proves to be positive and statistically significant, this revealing that the initial estimation could be somewhat masking the influence of market size as another important factor to attract FDI.

\subsubsection{Endogeneity}

\footnotetext{
21 Although population data are usually employed as weights, in this case we have opted for using employment data. This change tries to minimise the bias resulting from using population both as the weight in the WLS estimation and as one of the variables included in the market size factor.
} 
Another important aspect of the model is that related to the potential existence of endogeneity. To carry out this robustness check it is important to recall that, because of the use of factor analysis, it is really difficult to find a good instrument for the factors included in the regressions, as they are made up of several variables. For this reason, we have taken the decision to proceed as follows. First, and due to the high volatility of FDI data, we have used the well-known HP filter for estimating trends of fdi regional data; that is, our dependent variable is the trend in fdi. Second, coping with problems regarding data availability we have obtained data for the six factors for every year of the period 2000-2006. Third, we have run a two-stage least square regression using oneperiod lagged factors as instruments.

The fifth column of Table 10 confirms the role played by economic potential, labour market characteristics, technological progress, and competitiveness as FDI attraction factors. There are just two differences with previous results: first, that the labour regulation coefficient becomes positive and statistically significant; second, a remarkable increase in the influence of competitiveness.

\subsubsection{Top 50 FDI receiving regions}

Finally, taking into account that the top 50 FDI receiving regions concentrate more than $60 \%$ of total FDI inflows, we also want to discern whether the results obtained in Table 9 are still valid when only these regions are included in the sample. As the last column of Table 10 makes evident, the main difference is that the factor called labour market 
characteristics now becomes non-significant, that is, the influence of this factor vanishes. In any case, factors such as economic potential, technological progress and competitiveness continue playing a remarkable role in explaining FDI location patterns.

\section{Conclusions and policy implications}

As the EU is one of the main recipients of FDI in the world, this paper has examined its determinants at regional level over the period 2000-2006. The paper departs from previous analysis in four key aspects: first, it considers all EU regions rather than regions belonging just to a single country or a reduced number of them; second, it uses a database that provides information on the actual amount of regional inward FDI, whereas the small number of papers studying regional FDI in more than one EU country only employ information on the number of foreign firms established in them; third, it applies factor analysis to empirically select potential FDI drivers in a compact way; and fourth, it performs a large number of robustness tests that, leaving the main results of the paper essentially unchanged, also allows us to qualify them.

After reviewing the theoretical literature and offering an empirical survey for the EU regions, the paper analyses the FDI regional distribution as a previous step to examine its determinants. We obtain three interesting results. First, FDI shows a high degree of concentration; on average, 64\% of inward FDI is located in only 50 regions. Second, according to the FDI typology proposed by UNCTAD, 49 regions can be labelled as front-runners and 101 as under-performers; similarly, 46 regions exhibit above- 
potential and 64 exhibit below-potential performances. Third, EU regions are geographically concentrated around similar levels of inward FDI.

The second and main part of the paper, devoted to the study of FDI drivers, proceeds in four steps. We first specify the FDI model based on the theoretical and empirical literature on the topic. Then, we perform an exploratory factor analysis to reduce the large number of variables potentially affecting FDI to a manageable one. At this point, the best result obtained is made up of six factors, labelled as economic potential, market size, labour market characteristics, technological progress, labour regulation, and competitiveness. Afterwards, we estimate a reduced FDI equation in which we take, as independent variables, the six extracted factors, plus a dummy variable capturing regions located in cohesion countries (CF). In particular, we find that the main determinants of the location patterns of FDI in the EU regions are their economic potential, labour market characteristics, technological progress and competitiveness; in contrast, market size and labour regulation do not seem to exert any significant impact on these location patterns.

Finally, we carry out a robustness check of the results. The conclusions are very similar when controlling for outliers, spatial dependence, region's size, endogeneity and the top FDI receiving regions, which proves their robustness. In addition, this analysis conveys three important messages. First, inward FDI performance of a region is largely linked to that of its neighbours, this suggesting that a somewhat vague interpretation of agglomeration could also be regarded as an important factor in explaining FDI location. Second, market size could also be a factor attracting FDI, as we pointed out when taking 
into account region's size. Third, labour market characteristics factor becomes nonsignificant when we only include the top 50 regions of the sample, while labour regulation becomes significant when we deal with endogeneity.

Some general policy implications can be drawn from this analysis. First and above all, it seems clear that regions trying to attract more FDI should implement policies fostering what we have dubbed as their economic potential and competitiveness, and specifically the variables behind them. Additionally, measures trying to improve labour market characteristics and technological progress could be also pertinent because, although probably to a lesser extent, these factors also affect FDI location. In any case, bearing in mind the large number of regions in our sample and the huge economic differences among them, we also believe that regionally tailored policies would be the best option to remarkably increase FDI inflows. This really means that, although the European Commission and the various national governments can be helpful in this task, regional authorities should be directly involved in the design and implementation of policies focussed on the improvement of those specific economic factors in which their regions are relatively weak.

\section{References}

Ajami, R. \& Ricks, D. (1981). Motives of non-American firms investing in the United States. Journal of International Business Studies, 12(3), 25-34. 
Anselin, L. (1988). Spatial econometrics: Methods and models. Dordrecht, Kluwer Academic Publishers.

Anselin, L. \& Bera, A. (1998). Spatial dependence in linear regression models with an introduction to spatial econometrics. In A. Ullah and D. Giles (Eds.), Handbook of Applied Economic Statistics, pp. 237-289, New York, Marcel Dekker.

Barba, G. \& Venables, A. (2004). Multinational firms in the world economy. Princeton, Princeton University Press.

Barro, R. \& Sala-i-Martin, X. (2003). Economic growth. New York, McGraw-Hill, Inc.

Bartels, F.L., Napolitano, F. \& Tissi, N.E. (2013). FDI in Sub-Saharan Africa: A longitudinal perspective on location-specific factors (2003-2010). International Business Review (in press).

Basile, R., Castellani, D. \& Zanfei, A. (2008). Location choices of multinational firms in Europe: The role of EU cohesion policy. Journal of International Economics, 74, 328-340.

Basile, R., Castellani, D. \& Zanfei, A. (2009). National boundaries and the location of multinational firms in Europe. Papers in Regional Science, 88(4), 733-749.

Blonigen, B.A. (2005). A review of the empirical literature on FDI determinants. Atlantic Economic Journal, 33, 383-403.

Boermans, M.A., Roelfsema, H.J. \& Zhang, Y. (2011). Regional determinants of FDI in China: A factor-based approach. Journal of Chinese Economic and Business Studies, 9(1), 23-42.

Buckley, P.J. \& Casson. M. (1976). The future of multinational enterprise. London, Macmillan.

Capello, R., Fratesi, U. \& Resmini, L. (2011). Globalization and regional growth in Europe. Past trends and future scenarios. Berlin Heidelberg, Springer-Verlag. 
Casi, L. \& Resmini, L. (2010). Evidence on the determinants of foreign direct investment: The case of EU regions. Eastern Journal of European Studies, 1(2), 93118.

Castiglione, C., Gorbunova, Y., Infante, D. \& Smirnova, J. (2012). FDI determinants in an idiosyncratic country. A reappraisal over the Russian regions during transition years. Communist and Post- Communist Studies, 45, 1-10.

Caves, R. (1971). International corporations: The industrial economics of foreign investment. Economica, 38(149), 1-27.

Caves, R. (2007). Multinational enterprise and economic growth. Cambridge, CUP.

Chidlow, A., Salciuviene, L. \& Young, S. (2009). Regional determinants of inward FDI distribution in Poland. International Business Review, 18, 119-133.

Cook, M. (2010). Explaining the determinants of manufacturing and non-manufacturing FDI inflows in five UK regions. International Journal of Management Practice, 4(1), 1-26.

Crozet, M., Mayer, T. \& Mucchielli, J.L. (2004). How do firms agglomerate? A study of FDI in France. Regional Science and Urban Economics, 34, 27-54.

DiStefano, C., Zhu, M. \& Mîndrila, D. (2009). Understanding and using factor scores: Considerations for the applied researcher. Practical Assessment, Research \& Evaluation, 14(20), 1-11.

Dunning, J.H. (1977). Trade, location of economic activity and the MNE: A search for an eclectic approach. In: B. Ohlin, P.O. Hesselborn and P.M. Wijkman (Eds.), The International Allocation of Economic Activity, pp. 395-418, London, Holmes and Meier.

Dunning, J.H. (1979). Explaining changing pattern of international production: In defence of eclectic theory. Oxford Bulletin of Economics and Statistics, 41, 269296. 
Dunning, J.H. \& Lundan, S.M. (2008). Multinational enterprises and the global economy. Cheltenham, Edward Elgar.

EUROSTAT (2008). European Union foreign direct investment yearbook 2008. Luxembourg, European Commission.

Faeth, I. (2009). Determinants of foreign direct investment. A tale of nine theoretical models. Journal of Economic Surveys, 23(1), 165-196.

Fallon, G. \& Cook, M. (2010). Exploring the regional distribution of inbound foreign direct investment in the UK in theory and practice: Evidence from a five-region study. Regional Studies, 44(3), 337-353.

Fazekas, K. (2005). Effects of FDI inflows on regional labour market differences in Hungary. Economie Internationale, 102, 83-105.

Franco, C. (2013). Exports and FDI motivations: Empirical evidence from U.S. foreign subsidiaries. International Business Review, 22(1), 47-62.

Frigge, M, Hoaglin, D.C. \& Iglewicz, B. (1989). Some implementations of the boxplot. The American Statistician, 43(1), 50-54.

Grossman, G.M. \& Helpman, E. (1992). Innovation and growth in the global economy. Massachusetts, MIT Press.

Hymer, S.H. (1976). The international operations of national firms: A study of direct investment. Cambridge, MA, MIT Press.

Kemp, M.C. (1964). The pure theory of international trade. Englewood Cliffs, NJ, Prentice Hall.

Kindleberger, C.P. (1969). American business abroad: Six lectures on foreign direct investment. New Haven, CT, Yale University Press.

Knickerbocker, F.T. (1973). Oligopolistic reaction and multinational enterprise. Boston, MA, Harvard University Press. 
Lim, E.G. (2001). Determinants of, and the relation between, foreign direct investment and growth: A summary of the recent literature. IMF Working Paper No. 01/175.

López-Rodríguez, J., Faiña, A. \& Cosmin-Gabriel, B. (2011). Economic remoteness and wage disparities in Romania. Tijdschrift voor economische en sociale geografie, 102(5), 594-606.

MacDougall, G.D.A. (1960). The benefits and costs of private investment from abroad: A theoretical approach. Economic Record, 36, 205-266.

Majocchi, A. \& Presutti, M. (2009). Industrial clusters, entrepreneurial culture and the social environment: The effects on FDI distribution. International Business Review, 18, 76-88.

Maza, A. \& Villaverde, J. (2011). EU regional convergence and policy: Does the concept of region matter? Journal of Policy Modeling, 33, 889-900.

Nardo, M., Saisana, M., Salteyi, A. \& Tarantola, S. (2005). Handbook on constructing composite indicators: Methodology and user guide. OECD, STD/DOC 3.

Ottaviano, G. \& Puga, D. (1998). Agglomeration in the global economy: A survey of the 'new economic geography'. The World Economy, 21(6), 707-731.

Papalia, R.B. \& Bertarelli, S. (2009). The role of local agglomeration economies and regional characteristics in attracting FDI: Italian evidence. International Journal of the Economics and Business, 16(2), 161-188.

Park, H.Y. (2000). Foreign Direct Investment and Global Sourcing Choices of Firms in the US. Managerial and Decision Economics, 21, 211-221.

Pazienza, P. \& Vecchione, V. (2009). A preliminary investigation of the determinants of the FDI distribution in Italy. Journal of Business Economics and Management, 10(2), 99-107. 
Pelegrín, A. \& Bolancé, C. (2008). Regional foreign direct investment in manufacturing. Do agglomeration economies matter? Regional Studies, 42(4), 505522.

Polasek, W. \& Sellner, R. (2010). Spatial Chow-Lin methods for data completion in econometric flow models. IHS Economic Series No. 255, Institute for Advanced Studies.

Polasek, W. \& Sellner, R. (2011). Does globalization affect regional growth? Evidence for NUTS-2 regions in EU27. Institute for Advances Studies, Economic Series No. 266, Vienna.

Polasek, W., Llano, C. \& Sellner, R. (2010). Bayesian methods for completing data in spatial models. Review of Economic Analysis, 2, 194-214.

Redding, S.J. (2011). Economic geography, a review of the theoretical and empirical literature. In: D. Bernhofen, R. Falvey, D. Greenaway and U. Kreickemeier (Eds.), Palgrave Handbook of International Trade, pp. 497-531, Palgrave Macmillan.

Territorial Agenda (2007). Territorial agenda of the European Union: Towards a more competitive and sustainable Europe of diverse regions-Agreed at the occasion of the informal ministerial meeting on urban development and territorial cohesion on 24/25 May 2007. http:/www.eu-territorialagenda.eu/Reference\%20Documents/Territorial-Agenda-of-the-European-UnionAgreed-on-25-May-2007.pdf. Accessed 2 March 2014.

Tukey, J. (1977). Exploratory data analysis. Reading, MA, Addison- Wesley. UNCTAD (1999). World Investment Report, 1998. Trends and determinants. New York and Geneva, United Nations. 
UNCTAD (2001). World Investment Report, 2001. New York and Geneva, United Nations.

UNCTAD (2002). World Investment Report, 2002. New York and Geneva, United Nations.

Vernon, R. (1966). International investment and international trade in the product cycle. Quarterly Journal of Economics, 80, 190-207.

Villaverde, J. \& Maza, A. (2012). Foreign direct investment in Spain: Regional distribution and determinants. International Business Review, 21, 722-733.

Wren, C. \& Jones, J. (2012). FDI location across British regions and agglomerative forces: A Markov analysis. Spatial Economic Analysis, 7(2), 265-286. 


\section{Table 1. Host country/region determinants of FDI}

\begin{tabular}{|ll|}
\hline Host country determinants \\
\hline I. & Policy framework for FDI \\
\hline - & Economic, political and social \\
- & stability \\
& Rules regarding entry and \\
- & operations \\
& Standards of treatment of foreign \\
- & affiliates \\
& Policies on functioning and \\
& structure of markets (especially \\
- & competition and M\&A policies) \\
- & International agreements on FDI \\
- & Trivatization policy \\
& and coherence of FDI and trade \\
& policies \\
- & Tax policy \\
\hline II & Economic determinants \\
\hline III & Business facilitation \\
\hline$\bullet$ & Investment promotion (including \\
& image-building and investment- \\
& generating activities and \\
- & investment-facilitation services) \\
- & Investment incentives \\
& Hassle costs (related to \\
& corruption, administrative \\
- & Sfficiency, etc.) \\
- & Social amenities (bilingual \\
schools, quality of life, etc.) & After-investment services \\
\hline
\end{tabular}

\begin{tabular}{|c|c|c|}
\hline \multicolumn{2}{|c|}{$\begin{array}{l}\text { Type of FDI classified by } \\
\text { motives of TNCs }\end{array}$} & \multirow{2}{*}{$\begin{array}{ll}\text { Principal economic determinants in host countries } \\
\text { - } & \text { Market size and per capita income } \\
\text { - } & \text { Market growth } \\
\text { - } & \text { Access to regional and global markets } \\
\text { - } & \text { Structure of markets } \\
\end{array}$} \\
\hline A & Market-seeking & \\
\hline B & $\begin{array}{l}\text { Resource/asset- } \\
\text { seeking }\end{array}$ & $\begin{array}{ll} & \text { Raw materials } \\
\text { - } & \text { Low-cost unskilled labour } \\
\text { - } & \text { Skilled labour } \\
\text { - } & \text { Technological, innovatory and other created } \\
& \text { assets (e.g. brand names), including as embodied } \\
\text { in individuals, firms and clusters } \\
\text { - } & \begin{array}{l}\text { Physical infrastructure (ports, roads, power, } \\
\text { telecommunication) }\end{array} \\
\end{array}$ \\
\hline $\mathrm{C}$ & Efficiency-seeking & $\begin{array}{l}\text { Cost of resources and assets listed under B, } \\
\text { adjusted for productivity for labour resources } \\
\text { Other input costs, e.g. transport and } \\
\text { communication costs to/from and within host } \\
\text { economy and costs of other intermediate products } \\
\text { Membership of a regional integration agreement } \\
\text { conductive to the establishment of regional } \\
\text { corporate networks }\end{array}$ \\
\hline
\end{tabular}


Table 2. Inward FDI at regional level (average levels 2000-06)

\begin{tabular}{|c|c|c|c|}
\hline & \multicolumn{3}{|c|}{ FDI } \\
\hline & Code & Region & Value \\
\hline \multirow{10}{*}{ Top 10} & fr10 & Île de France & 35503 \\
\hline & be10 & Bruxelles & 11434 \\
\hline & se11 & Stockholm & 9504 \\
\hline & be21 & Antwerpen & 8311 \\
\hline & es30 & Comunidad de Madrid & 7232 \\
\hline & ukg3 & West Midlands & 6322 \\
\hline & $\mathrm{dk} 00$ & DENMARK & 6144 \\
\hline & be24 & Prov. Vlaams Brabant & 6138 \\
\hline & nl33 & Zuid-Holland & 5999 \\
\hline & uki1 & Inner London & 5902 \\
\hline \multirow{10}{*}{ Bottom 10} & gr14 & Thessalia & 7 \\
\hline & itc2 & Valle dAosta/Vallée dAoste & 6 \\
\hline & gr12 & Kentriki Makedonia & 5 \\
\hline & gr41 & Voreio Aigaio & 2 \\
\hline & gr42 & Notio Aigaio & 2 \\
\hline & gr21 & Ipeiros & 1 \\
\hline & gr22 & Ionia Nisia & -1 \\
\hline & gr13 & Dytiki Makedonia & -18 \\
\hline & gr23 & Dytiki Ellada & -19 \\
\hline & gr25 & Peloponnisos & -62 \\
\hline
\end{tabular}

Note: All figures are expressed in millions of euros of the year 2000. 
Table 3. Inward FDI concentration at regional level

\begin{tabular}{|l|r|r|r|}
\hline Period & Top 10 & Top 30 & Top 50 \\
\hline 2000 & 33.5 & 59.9 & 74.8 \\
\hline 2001 & 37.2 & 65.7 & 84.8 \\
\hline 2002 & 163.5 & 222.8 & 250.7 \\
\hline 2003 & 33.6 & 60.5 & 77.4 \\
\hline 2004 & 57.5 & 82.8 & 95.6 \\
\hline 2005 & 43.0 & 65.4 & 78.8 \\
\hline 2006 & 32.1 & 55.0 & 68.3 \\
\hline $2000-06$ & 30.6 & 52.0 & 64.3 \\
\hline
\end{tabular}

Note: The year 2002 is rather remarkable mostly because the significant disinvestment in some regions led to a huge increase in the FDI concentration of well over $100 \%$. The concentration indices for the period 2000-06 are computed by adding FDI flows for all years. 


\section{Map 1. Regional classification by FDI Performance and Potential Indices}

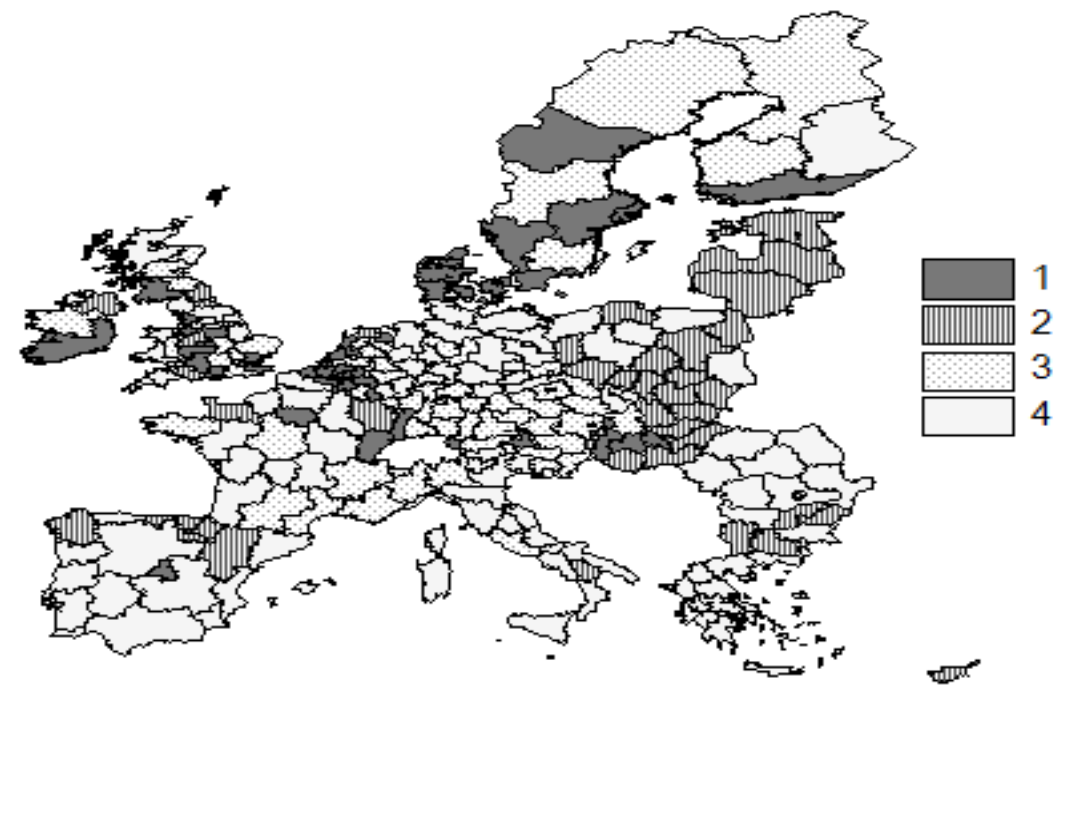

Note: 1. Front-runners; 2. Above-potential economies; 3. Below-potential economies; 4. Underperformers 
Table 4. Moran's I statistic

\begin{tabular}{|l|r|r|r|}
\hline Period & Moran's I & z value & $\boldsymbol{p}$ value \\
\hline 2000 & $0.079^{* * *}$ & 14.214 & 0.000 \\
\hline 2001 & $0.086^{* * *}$ & 15.342 & 0.000 \\
\hline 2002 & $0.049^{* * *}$ & 9.093 & 0.000 \\
\hline 2003 & -0.001 & 0.411 & 0.681 \\
\hline 2004 & $0.048^{* * *}$ & 8.924 & 0.000 \\
\hline 2005 & $0.097^{* * *}$ & 17.330 & 0.000 \\
\hline 2006 & $0.045^{* * *}$ & 8.357 & 0.000 \\
\hline $2000-06$ & $0.060^{* * *}$ & 11.019 & 0.000 \\
\hline
\end{tabular}

Note: $\left(^{* * *}\right)$ denotes significance at the $1 \%$ level. 
Table 5. Regional explanatory variables

\begin{tabular}{|c|c|c|c|c|c|}
\hline Code & Meaning & Definition (if necessary) & Units & Source & Years \\
\hline OP & Openness Degree & $\begin{array}{l}\text { Exports plus Imports over } \\
\text { GDP }\end{array}$ & $\%$ & $\begin{array}{l}\text { Polasek and } \\
\text { Sellner }\end{array}$ & 2000-2006 \\
\hline GDP & Gross Added Value & & $\begin{array}{l}\text { Constant } \\
\text { mio euros } \\
2000 \\
\end{array}$ & $\begin{array}{l}\text { Cambridge } \\
\text { Econometrics }\end{array}$ & 2000-2006 \\
\hline $\mathrm{PO}$ & Population & & Thousands & $\begin{array}{l}\text { Cambridge } \\
\text { Econometrics }\end{array}$ & 2000-2006 \\
\hline GDPpc & $\begin{array}{l}\text { Per capita Gross Added } \\
\text { Value }\end{array}$ & GDP over Population & $\begin{array}{l}\text { Constant } \\
\text { euros } 2000\end{array}$ & $\begin{array}{l}\text { Cambridge } \\
\text { Econometrics }\end{array}$ & 2000-2006 \\
\hline LP & Labour Productivity & GDP over Total Employment & $\begin{array}{l}\text { Constant } \\
\text { euros } 2000\end{array}$ & $\begin{array}{l}\text { Cambridge } \\
\text { Econometrics }\end{array}$ & 2000-2006 \\
\hline MSHARE & Manufacturing Share & $\begin{array}{l}\text { Manufacturing Employment } \\
\text { over Total Employment }\end{array}$ & $\%$ & $\begin{array}{l}\text { Cambridge } \\
\text { Econometrics }\end{array}$ & 2000-2006 \\
\hline $\mathrm{W}$ & $\begin{array}{l}\text { Compensation per } \\
\text { Employee }\end{array}$ & $\begin{array}{l}\text { Remuneration over } \\
\text { Employment }\end{array}$ & $\begin{array}{l}\text { Constant } \\
\text { euros } 2000\end{array}$ & $\begin{array}{l}\text { Cambridge } \\
\text { Econometrics }\end{array}$ & 2000-2006 \\
\hline URinv & $\begin{array}{l}\text { (Inverse of) Unemployment } \\
\text { Rate }\end{array}$ & & $\%$ & $\begin{array}{l}\text { Cambridge } \\
\text { Econometrics }\end{array}$ & 2000-2006 \\
\hline LTURinv & $\begin{array}{l}\text { (Inverse of) Long-term } \\
\text { Unemployment Rate }\end{array}$ & & $\%$ & Eurostat & Selected years \\
\hline ER & Employment Rate & & $\%$ & $\begin{array}{l}\text { Cambridge } \\
\text { Econometrics }\end{array}$ & 2000-2006 \\
\hline $\mathrm{AR}$ & Activity Rate & & $\%$ & $\begin{array}{l}\text { Cambridge } \\
\text { Econometrics }\end{array}$ & 2000-2006 \\
\hline INV & Investment & & $\begin{array}{l}\text { Constant } \\
\text { meuros } 2000\end{array}$ & $\begin{array}{l}\text { Cambridge } \\
\text { Econometrics }\end{array}$ & 2000-2006 \\
\hline TWinv & $\begin{array}{l}\text { (Inverse of) Tax Wedge on } \\
\text { Employment }\end{array}$ & $\begin{array}{l}\text { Labour Taxes over Total } \\
\text { Labour Costs }\end{array}$ & $\%$ & Eurostat & 2000-2006 \\
\hline R\&D & R\&D Expenditure & R\&D Expenditure over GDP & $\%$ & Eurostat & Selected years \\
\hline $\mathrm{R} \& \mathrm{DP}$ & R\&D Personnel & $\begin{array}{l}\text { R\&D Personnel over Active } \\
\text { Population }\end{array}$ & $\%$ & Eurostat & Selected years \\
\hline HTC & High Technology Sectors & $\begin{array}{l}\text { High Technology } \\
\text { Employment over Total } \\
\text { Employment }\end{array}$ & $\%$ & Eurostat & Selected years \\
\hline $\mathrm{HC}$ & Human Capital & Students at ISCED levels 5-6 & $\%$ & Eurostat & Selected years \\
\hline MULA & $\begin{array}{l}\text { Air and Multimodal } \\
\text { Accessibility }\end{array}$ & $\begin{array}{l}\text { An index combining several } \\
\text { modal accessibility } \\
\text { indicators, such as road, air, } \\
\text { inland waterways and rail. } \\
\text { The higher the index, , the } \\
\text { higher the accessibility }\end{array}$ & $\begin{array}{l}\text { Synthetic } \\
\text { index: } \\
\text { EU }=100\end{array}$ & Espon & 2001 and 2006 \\
\hline LLRinv & $\begin{array}{l}\text { (Inverse of) Labour Law } \\
\text { Rigidity }\end{array}$ & $\begin{array}{l}\text { Average of indexes for } \\
\text { alternative employment } \\
\text { contracts, cost of increasing } \\
\text { working hours, of firing } \\
\text { workers and dismissal } \\
\text { procedures. The lower the } \\
\text { index, the higher the rigidity }\end{array}$ & $\begin{array}{l}\text { Synthetic } \\
\text { index (0- } \\
100)\end{array}$ & $\begin{array}{l}\text { World Bank / } \\
\text { Doing Business }\end{array}$ & 2004 \\
\hline LMR & Labour Market Regulation & $\begin{array}{l}\text { An index giving high marks } \\
\text { to countries allowing market } \\
\text { forces to regulate wages and } \\
\text { establish the conditions of } \\
\text { dismissal, circumvent } \\
\text { excessive unemployment } \\
\text { benefits and refrain from the } \\
\text { use of conscription }\end{array}$ & $\begin{array}{l}\text { Synthetic } \\
\text { index }(0-10)\end{array}$ & $\begin{array}{l}\text { Fraser Institute / } \\
\text { Economic Freedom } \\
\text { of the World } \\
\text { Annual Reports }\end{array}$ & 2000 and 2005 \\
\hline MP & Market Potential & (See note) & $\begin{array}{l}\text { Constant } \\
\text { meuros } 2000\end{array}$ & $\begin{array}{l}\text { Own elaboration } \\
\text { based on } \\
\text { Cambridge } \\
\text { Econometrics }\end{array}$ & 2000-2006 \\
\hline
\end{tabular}

Note: Market potential for region $i$ is calculated as follows:

$$
M P_{i}=\sum_{i \neq j} w_{i j} * G D P_{j}
$$

where $w_{i j}$ are the elements of the distance matrix $W$ between each pair of regions $(i, j)$. Once again, we have used the inverse of the standardised distance as a distance matrix. 
Table 6. Regional explanatory variables: Summary statistics

\begin{tabular}{|l|c|c|c|c|c|}
\hline Code & Mean & Decile 1 & Decile 9 & $\begin{array}{c}\text { Decile 9/ } \\
\text { Decile 1 }\end{array}$ & $\begin{array}{c}\text { Coef. } \\
\text { Variation }\end{array}$ \\
\hline OP & 69.67 & 38.10 & 118.94 & 3.12 & 0.55 \\
\hline GDP & 36155 & 5088 & 78441 & 15.42 & 1.18 \\
\hline PO & 1836 & 487 & 3678 & 7.55 & 0.80 \\
\hline GDPpc & 19278 & 4376 & 30039 & 6.86 & 0.53 \\
\hline LP & 42482 & 11792 & 60408 & 5.12 & 0.44 \\
\hline MSHARE & 19.35 & 10.02 & 28.50 & 2.84 & 0.37 \\
\hline W & 20747 & 5214 & 30566 & 5.86 & 0.48 \\
\hline URinv & 0.1544 & 0.0601 & 0.2673 & 4.45 & 0.53 \\
\hline LTURinv & 0.5377 & 0.1140 & 1.2303 & 10.79 & 1.01 \\
\hline ER & 43.17 & 34.63 & 50.82 & 1.47 & 0.15 \\
\hline AR & 47.18 & 40.38 & 53.51 & 1.33 & 0.12 \\
\hline INV & 7185 & 1100 & 14478 & 13.16 & 1.16 \\
\hline TWinv & 0.0260 & 0.0212 & 0.0342 & 1.61 & 0.21 \\
\hline R\&D & 1.38 & 0.25 & 3.14 & 12.38 & 0.89 \\
\hline R\&DP & 1.23 & 0.36 & 2.42 & 6.77 & 0.71 \\
\hline HTC & 4.05 & 1.73 & 6.51 & 3.75 & 0.44 \\
\hline HC & 14.58 & 8.53 & 22.53 & 2.64 & 0.42 \\
\hline MULA & 93.84 & 46.88 & 141.24 & 3.01 & 0.38 \\
\hline LLRinv & 0.0222 & 0.0149 & 0.0357 & 2.39 & 0.32 \\
\hline LMR & 5.29 & 3.40 & 7.70 & 2.27 & 0.25 \\
\hline MP & 37677 & 26973 & 44643 & 1.66 & 0.18 \\
\hline
\end{tabular}


Table 7. Factor analysis. Total variance explained

\begin{tabular}{|l|r|r|r|}
\hline Factor & Eigenvalue & \% Variance & $\begin{array}{r}\text { \% Cumulative } \\
\text { variance }\end{array}$ \\
\hline $\mathbf{1}$ & $\mathbf{7 . 4 8 4}$ & $\mathbf{3 5 . 6 3 9}$ & $\mathbf{3 5 . 6 3 9}$ \\
\hline $\mathbf{2}$ & $\mathbf{3 . 2 6 9}$ & $\mathbf{1 5 . 5 6 8}$ & $\mathbf{5 1 . 2 0 6}$ \\
\hline $\mathbf{3}$ & $\mathbf{1 . 9 5 7}$ & $\mathbf{9 . 3 2 1}$ & $\mathbf{6 0 . 5 2 7}$ \\
\hline $\mathbf{4}$ & $\mathbf{1 . 7 3 6}$ & $\mathbf{8 . 2 6 7}$ & $\mathbf{6 8 . 7 9 4}$ \\
\hline $\mathbf{5}$ & $\mathbf{1 . 4 5 4}$ & $\mathbf{6 . 9 2 2}$ & $\mathbf{7 5 . 7 1 7}$ \\
\hline $\mathbf{6}$ & $\mathbf{1 . 1 0 5}$ & $\mathbf{5 . 2 6 1}$ & $\mathbf{8 0 . 9 7 7}$ \\
\hline 7 & 0.799 & 3.806 & 84.784 \\
\hline 8 & 0.741 & 3.531 & 98.314 \\
\hline 9 & 0.546 & 2.601 & 90.915 \\
\hline 10 & 0.517 & 2.462 & 93.377 \\
\hline 11 & 0.352 & 1.678 & 95.054 \\
\hline 12 & 0.296 & 1.412 & 96.466 \\
\hline 13 & 0.260 & 1.236 & 97.702 \\
\hline 14 & 0.134 & 0.639 & 98.341 \\
\hline 15 & 0.115 & 0.550 & 98.891 \\
\hline 16 & 0.092 & 0.438 & 99.329 \\
\hline 17 & 0.063 & 0.300 & 99.629 \\
\hline 18 & 0.035 & 0.165 & 99.793 \\
\hline 19 & 0.017 & 0.080 & 99.874 \\
\hline 20 & 0.016 & 0.076 & 99.949 \\
\hline 21 & 0.011 & 0.051 & 100.000 \\
\hline
\end{tabular}

Note: In bold factors with eigenvalue greater than 1. 
Table 8. Factor analysis. Rotated component matrix

\begin{tabular}{|l|r|r|r|r|r|r|r|}
\hline Variable & F1 & F2 & F3 & F4 & F5 & F6 & Communalities \\
\hline OP & -0.042 & -0.207 & -0.093 & 0.051 & 0.068 & $\mathbf{0 . 8 1 7}$ & 0.729 \\
\hline GDP & 0.346 & $\mathbf{0 . 8 9 3}$ & 0.103 & 0.157 & -0.019 & -0.076 & 0.959 \\
\hline PO & -0.071 & $\mathbf{0 . 9 5 2}$ & -0.043 & 0.049 & -0.053 & -0.038 & 0.920 \\
\hline GDPpc & $\mathbf{0 . 8 3 5}$ & 0.136 & 0.348 & 0.253 & 0.033 & -0.124 & 0.917 \\
\hline LP & $\mathbf{0 . 9 3 1}$ & 0.116 & 0.149 & 0.183 & -0.025 & -0.105 & 0.947 \\
\hline MSHARE & -0.126 & 0.043 & 0.184 & -0.052 & -0.100 & $\mathbf{0 . 7 1 7}$ & 0.579 \\
\hline W & $\mathbf{0 . 9 2 9}$ & 0.120 & 0.168 & 0.189 & 0.008 & -0.054 & 0.944 \\
\hline Urinv & 0.393 & -0.106 & $\mathbf{0 . 6 6 7}$ & -0.048 & 0.338 & 0.085 & 0.734 \\
\hline LTURinv & 0.376 & -0.216 & $\mathbf{0 . 5 7 7}$ & -0.066 & 0.392 & -0.072 & 0.685 \\
\hline ER & 0.230 & 0.126 & $\mathbf{0 . 8 9 8}$ & 0.196 & 0.128 & 0.068 & 0.934 \\
\hline AR & 0.112 & 0.168 & $\mathbf{0 . 8 7 3}$ & 0.218 & 0.034 & 0.035 & 0.853 \\
\hline INV & 0.301 & $\mathbf{0 . 9 0 3}$ & 0.085 & 0.142 & -0.064 & -0.079 & 0.943 \\
\hline TWinv & -0.119 & -0.047 & 0.125 & -0.071 & $\mathbf{0 . 6 6 2}$ & -0.435 & 0.664 \\
\hline R\&D & 0.444 & 0.097 & 0.220 & $\mathbf{0 . 6 6 4}$ & -0.048 & 0.200 & 0.738 \\
\hline R\&DP & 0.342 & 0.102 & 0.200 & $\mathbf{0 . 8 5 5}$ & 0.004 & 0.018 & 0.898 \\
\hline HTC & 0.437 & 0.251 & 0.285 & $\mathbf{0 . 5 3 7}$ & 0.250 & 0.251 & 0.748 \\
\hline HC & -0.324 & 0.141 & -0.093 & $\mathbf{0 . 6 7 8}$ & -0.122 & -0.330 & 0.717 \\
\hline MULA & $\mathbf{0 . 5 9 9}$ & 0.347 & 0.216 & 0.314 & 0.024 & 0.306 & 0.719 \\
\hline LLRinv & 0.345 & -0.075 & 0.336 & 0.064 & $\mathbf{0 . 7 0 8}$ & 0.030 & 0.744 \\
\hline LMR & -0.030 & -0.009 & 0.065 & -0.020 & $\mathbf{0 . 9 3 9}$ & 0.113 & 0.901 \\
\hline MP & $\mathbf{0 . 8 0 5}$ & 0.143 & 0.142 & -0.123 & 0.158 & -0.044 & 0.731 \\
\hline N & & & & &
\end{tabular}

Note: In bold the factor in which each variable loads higher. 
Table 9. FDI determinants. Reduced model

\begin{tabular}{|l|r|r|}
\hline Exogenous variables & Sum scores & Regression scores \\
\hline \multirow{2}{*}{ Economic potential (F1) } & $0.028^{* * *}$ & $0.023^{* * *}$ \\
& $(0.000)$ & $(0.000)$ \\
\hline \multirow{2}{*}{ Market size (F2) } & $0.009^{* * *}$ & $0.018^{* * *}$ \\
& $(0.003)$ & $(0.000)$ \\
\hline Labour market characteristics (F3) & 0.001 & 0.000 \\
& $(0.723)$ & $(0.843)$ \\
\hline Technological progress (F4) & $0.006^{* *}$ & $0.006^{* *}$ \\
& $(0.029)$ & $(0.013)$ \\
\hline Labour regulation (F5) & $0.008^{* * *}$ & $0.010^{* * *}$ \\
& $(0.002)$ & $(0.000)$ \\
\hline Competitiveness (F6) & -0.001 & 0.002 \\
& $(0.573)$ & $(0.324)$ \\
\hline CF & $0.018^{* * *}$ & $0.011^{* * *}$ \\
& $(0.000)$ & $(0.000)$ \\
\hline R-square & $0.016^{* * *}$ & $0.036^{* * *}$ \\
\hline LIK & $(0.008)$ & $(0.000)$ \\
\hline AIC & 0.24 & 0.21 \\
\hline SC & 497.792 & 492.023 \\
\hline Number of observations & -979.584 & -968.047 \\
\hline Not & -950.946 & -939.409 \\
\hline F & 260 & 260 \\
\hline
\end{tabular}

Note: $(* * *),(* *)$ and $(*)$ denote significance at $1 \%, 5 \%$ and $10 \%$ levels; p-values in brackets. 
Figure 1. European fdi distribution at regional level

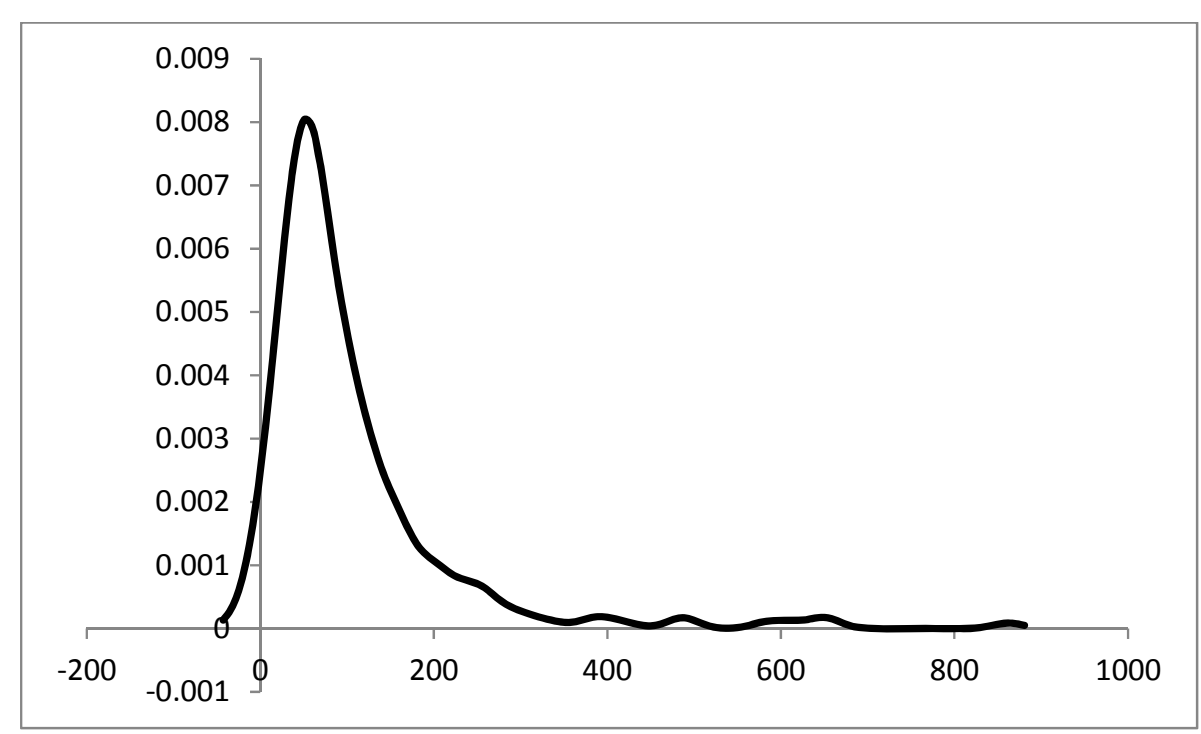

Note: The density function is estimated by using a Gaussian kernel function with optimal bandwidth according to Silverman's rule-of-thumb. 
Table 10. FDI determinants. Robustness check

\begin{tabular}{|c|c|c|c|c|c|c|}
\hline \multirow{3}{*}{ Exogenous variables } & \multicolumn{6}{|c|}{ Regression scores } \\
\hline & \multicolumn{2}{|c|}{ Outliers } & \multirow{2}{*}{$\begin{array}{c}\text { Spatial } \\
\text { dependence }\end{array}$} & \multirow[b]{2}{*}{ Size } & \multirow[b]{2}{*}{ Endogeneity } & \multirow{2}{*}{$\begin{array}{l}\text { Top } 50 \\
\text { regions }\end{array}$} \\
\hline & $\begin{array}{c}\text { Removing } \\
\text { outliers }\end{array}$ & $\begin{array}{c}\text { Quantile } \\
\text { regression }\end{array}$ & & & & \\
\hline C & $\begin{array}{r}0.019 * * * \\
(0.000)\end{array}$ & $\begin{array}{r}0.016 * * * \\
(0.000)\end{array}$ & $\begin{array}{c}-0.007^{*} \\
(0.073) \\
\end{array}$ & $\begin{array}{r}0.016^{* * * *} \\
(0.000) \\
\end{array}$ & $\begin{array}{r}0.036^{* * *} \\
(0.000) \\
\end{array}$ & $\begin{array}{r}0.022 \\
(0.235) \\
\end{array}$ \\
\hline Economic potential $\left(F_{1}\right)$ & $\begin{array}{r}0.008 * * * \\
(0.000) \\
\end{array}$ & $\begin{array}{r}0.009 * * * \\
(0.000) \\
\end{array}$ & $\begin{array}{r}0.013^{* * * *} \\
(0.000) \\
\end{array}$ & $\begin{array}{r}0.010 * * * \\
(0.001) \\
\end{array}$ & $\begin{array}{r}0.008 * * * \\
(0.000) \\
\end{array}$ & $\begin{array}{r}0.028 * * \\
(0.043) \\
\end{array}$ \\
\hline Market size $\left(F_{2}\right)$ & $\begin{array}{r}0.001 \\
(0.421)\end{array}$ & $\begin{array}{r}-0.0001 \\
(0.55)\end{array}$ & $\begin{array}{r}-0.001 \\
(0.788)\end{array}$ & $\begin{array}{r}0.004^{* * *} \\
(0.000)\end{array}$ & $\begin{array}{r}-0.002 \\
(0.208)\end{array}$ & $\begin{array}{r}-0.003 \\
(0.662)\end{array}$ \\
\hline $\begin{array}{l}\text { Labour market } \\
\text { characteristics }\left(F_{3}\right)\end{array}$ & $\begin{array}{r}0.004^{* * *} \\
(0.001)\end{array}$ & $\begin{array}{r}0.005^{* * *} \\
(0.000)\end{array}$ & $\begin{array}{r}0.006^{* *} \\
(0.014)\end{array}$ & $\begin{array}{r}0.005 * * \\
(0.032)\end{array}$ & $\begin{array}{c}0.002 * \\
(0.078)\end{array}$ & $\begin{array}{r}0.005 \\
(0.596)\end{array}$ \\
\hline $\begin{array}{l}\text { Technological progress } \\
\left(F_{4}\right)\end{array}$ & $\begin{array}{r}0.005^{* * * *} \\
(0.000)\end{array}$ & $\begin{array}{r}0.006^{* * *} \\
(0.001)\end{array}$ & $\begin{array}{r}0.010 * * * \\
(0.000)\end{array}$ & $\begin{array}{r}0.014^{* * * *} \\
(0.000)\end{array}$ & $\begin{array}{r}0.015^{* * * *} \\
(0.000)\end{array}$ & $\begin{array}{r}0.014^{* *} \\
(0.041)\end{array}$ \\
\hline Labour regulation $\left(F_{5}\right)$ & $\begin{array}{r}0.001 \\
(0.463) \\
\end{array}$ & $\begin{array}{r}0.000 \\
(0.863)\end{array}$ & $\begin{array}{r}0.003 \\
(0.198) \\
\end{array}$ & $\begin{array}{r}0.003 \\
(0.206) \\
\end{array}$ & $\begin{array}{r}0.005^{* * *} \\
(0.000)\end{array}$ & $\begin{array}{r}0.007 \\
(0.398) \\
\end{array}$ \\
\hline Competitiveness $\left(F_{6}\right)$ & $\begin{array}{r}0.007^{* * * *} \\
(0.000) \\
\end{array}$ & $\begin{array}{r}0.009^{* * * *} \\
(0.000) \\
\end{array}$ & $\begin{array}{r}0.008^{* * * *} \\
(0.001)\end{array}$ & $\begin{array}{r}0.010^{* * * *} \\
(0.003)\end{array}$ & $\begin{array}{r}0.035^{* * * *} \\
(0.000)\end{array}$ & $\begin{array}{r}0.022 * * * \\
(0.004)\end{array}$ \\
\hline$C F$ & $\begin{array}{r}0.015^{* * * *} \\
(0.000) \\
\end{array}$ & $\begin{array}{r}0.028 * * * \\
(0.000) \\
\end{array}$ & $\begin{array}{r}0.031^{* * * *} \\
(0.000) \\
\end{array}$ & $\begin{array}{r}0.033^{* * * *} \\
(0.000) \\
\end{array}$ & $\begin{array}{r}0.013^{* * * *} \\
(0.000) \\
\end{array}$ & $\begin{array}{r}0.100 * * * \\
(0.004)\end{array}$ \\
\hline$W_{\_} f d i$ & & & $\begin{array}{r}0.899 * * * \\
(0.000) \\
\end{array}$ & & & \\
\hline R-square & 0.22 & 0.24 & & 0.28 & 0.37 & 0.29 \\
\hline LIK & & & 501.501 & & & \\
\hline AIC & & & -985.003 & & & \\
\hline SC & & & -952.785 & & & \\
\hline Number of Observations & 239 & 260 & 260 & 260 & 1560 & 50 \\
\hline
\end{tabular}

Note: $\left({ }^{* *}\right),\left({ }^{* *}\right)$ and $\left({ }^{*}\right)$ denote significance at $1 \%, 5 \%$ and $10 \%$ levels; p-values in brackets. 
Table 11. Spatial tests

\begin{tabular}{|l|r|}
\hline Tests & Regression scores \\
\hline LM-ERR & $31.455^{* * *}$ \\
& $(0.000)$ \\
\hline LM-EL & 0.362 \\
& $(0.548)$ \\
\hline LM-LAG & $41.604^{* * *}$ \\
& $(0.000)$ \\
\hline LM-LE & $10.510^{* * *}$ \\
& $(0.001)$ \\
\hline
\end{tabular}

Note: LM-ERR = Lagrange multiplier for spatial errors; LM-EL = LM-ERR associated robust; LMLAG = Lagrange multiplier for spatial lags; LM-LE = LM-LAG associated robust. $(* * *)$ denote significance at the $1 \%$ level; p-values in brackets. 


\section{APPENDIX}

Table A.1. FDI Performance and Potential Indices. Regional classification (Average 2000-2006)

\begin{tabular}{|c|c|c|c|c|}
\hline Code & Region & Performance Index & Potential Index & $\begin{array}{r}\text { Regional } \\
\text { classification }\end{array}$ \\
\hline at11 & Burgenland & 117.0 & 21.8 & 2 \\
\hline at12 & Niederösterreich & 68.2 & 24.9 & 3 \\
\hline at13 & Wien & 193.5 & 44.8 & 1 \\
\hline at21 & Kärnten & 76.5 & 31.6 & 3 \\
\hline at22 & Steiermark & 74.0 & 34.5 & 3 \\
\hline at31 & Oberösterreich & 70.2 & 31.8 & 3 \\
\hline at32 & Salzburg & 103.7 & 28.2 & 1 \\
\hline at33 & Tirol & 69.7 & 32.4 & 3 \\
\hline at34 & Vorarlberg & 130.6 & 35.7 & 1 \\
\hline be10 & Brussels & 650.7 & 43.5 & 1 \\
\hline be21 & Antwerpen & 484.3 & 50.8 & 1 \\
\hline be22 & Limburg & 390.2 & 42.9 & 1 \\
\hline be23 & Oost-Vlaanderen & 226.0 & 41.1 & 1 \\
\hline be24 & Vlaams Brabant & 650.0 & 50.0 & 1 \\
\hline be25 & West-Vlaanderen & 297.2 & 36.6 & 1 \\
\hline be31 & Brabant Wallon & 243.2 & 65.9 & 1 \\
\hline be32 & Hainaut & 164.3 & 34.5 & 1 \\
\hline be33 & Liège & 200.7 & 38.7 & 1 \\
\hline be34 & Luxembourg & 58.7 & 35.6 & 3 \\
\hline be35 & Namur & 286.1 & 36.0 & 1 \\
\hline bg31 & Severozapaden & 24.0 & 16.5 & 4 \\
\hline bg32 & Severen tsentralen & 140.0 & 14.9 & 2 \\
\hline bg33 & Severoiztochen & 250.6 & 11.2 & 2 \\
\hline bg34 & Yugoiztochen & 53.2 & 16.0 & 4 \\
\hline bg41 & Yugozapaden & 583.2 & 20.2 & 2 \\
\hline bg42 & Yuzhen tsentralen & 102.9 & 13.5 & 2 \\
\hline cy00 & CYPRUS & 263.1 & 11.0 & 2 \\
\hline $\mathrm{cz01}$ & Praha & 610.3 & 35.8 & 1 \\
\hline $\mathrm{cz02}$ & Strední Cechy & 52.1 & 34.8 & 3 \\
\hline $\mathrm{cz03}$ & Jihozápad & 42.9 & 26.5 & 3 \\
\hline cz04 & Severozápad & 42.7 & 23.3 & 4 \\
\hline cz05 & Severovýchod & 52.7 & 25.9 & 3 \\
\hline cz06 & Jihovýchod & 55.9 & 25.8 & 3 \\
\hline $\mathrm{cz07}$ & Strední Morava & 55.0 & 23.4 & 4 \\
\hline cz08 & Moravskoslezsko & 49.4 & 20.2 & 4 \\
\hline de11 & Stuttgart & 61.4 & 48.3 & 3 \\
\hline de12 & Karlsruhe & 71.7 & 46.6 & 3 \\
\hline de13 & Freiburg & 70.0 & 38.1 & 3 \\
\hline de14 & Tübingen & 66.6 & 41.8 & 3 \\
\hline de21 & Oberbayern & 70.0 & 50.2 & 3 \\
\hline de22 & Niederbayern & 39.9 & 31.9 & 3 \\
\hline de23 & Oberpfalz & 36.8 & 30.3 & 3 \\
\hline de24 & Oberfranken & 32.6 & 24.6 & 4 \\
\hline de25 & Mittelfranken & 55.7 & 36.5 & 3 \\
\hline de26 & Unterfranken & 52.4 & 27.7 & 3 \\
\hline de27 & Schwaben & 53.5 & 27.4 & 3 \\
\hline de30 & Berlin & 85.6 & 34.3 & 3 \\
\hline de41 & Brandenburg - Nordost & 38.6 & 16.5 & 4 \\
\hline de42 & Brandenburg - Südwest & 54.9 & 20.6 & 4 \\
\hline de50 & Bremen & 110.2 & 32.1 & 1 \\
\hline de60 & Hamburg & 199.1 & 34.7 & 1 \\
\hline de71 & Darmstadt & 56.8 & 39.8 & 3 \\
\hline de72 & Gießen & 61.5 & 28.9 & 3 \\
\hline de73 & Kassel & 40.0 & 22.6 & 4 \\
\hline de80 & Mecklenburg-Vorpommern & 22.7 & 16.0 & 4 \\
\hline de91 & Braunschweig & 25.3 & 43.9 & 3 \\
\hline de92 & Hannover & 36.9 & 27.1 & 3 \\
\hline de93 & Lüneburg & 31.7 & 16.5 & 4 \\
\hline de94 & Weser-Ems & 42.7 & 17.8 & 4 \\
\hline dea1 & Düsseldorf & 39.8 & 28.8 & 3 \\
\hline dea2 & Köln & 71.0 & 33.9 & 3 \\
\hline dea3 & Münster & 54.3 & 20.8 & 4 \\
\hline dea4 & Detmold & 44.8 & 23.6 & 4 \\
\hline dea5 & Arnsberg & 34.2 & 23.8 & 4 \\
\hline
\end{tabular}




\begin{tabular}{|c|c|c|c|c|}
\hline deb1 & Koblenz & 50.6 & 21.3 & 4 \\
\hline deb2 & Trier & 53.5 & 22.1 & 4 \\
\hline deb3 & Rheinhessen-Pfalz & 60.4 & 31.4 & 3 \\
\hline $\operatorname{dec} 0$ & Saarland & 41.3 & 25.2 & 3 \\
\hline ded1 & Chemnitz & 50.5 & 19.5 & 4 \\
\hline ded2 & Dresden & 80.0 & 31.6 & 3 \\
\hline ded3 & Leipzig & 31.4 & 23.6 & 4 \\
\hline dee0 & Sachsen-Anhalt & 42.2 & 16.5 & 4 \\
\hline def0 & Schleswig-Holstein & 20.5 & 22.7 & 4 \\
\hline $\operatorname{deg} 0$ & Thüringen & 58.0 & 22.4 & 4 \\
\hline $\mathrm{dk} 00$ & Denmark & 98.4 & 35.9 & 1 \\
\hline ee00 & Estonia & 310.4 & 24.8 & 2 \\
\hline es11 & Galicia & 135.9 & 11.3 & 2 \\
\hline es12 & Asturias & 92.0 & 12.9 & 4 \\
\hline es13 & Cantabria & 154.5 & 12.6 & 2 \\
\hline es21 & Pais Vasco & 153.8 & 21.7 & 2 \\
\hline es22 & Navarra & 163.9 & 20.3 & 2 \\
\hline es23 & La Rioja & 222.9 & 15.1 & 2 \\
\hline es24 & Aragón & 220.2 & 16.8 & 2 \\
\hline es30 & Madrid & 169.3 & 30.4 & 1 \\
\hline es41 & Castilla y León & 61.4 & 12.9 & 4 \\
\hline es42 & Castilla-la Mancha & 29.8 & 9.4 & 4 \\
\hline es43 & Extremadura & 3.1 & 9.0 & 4 \\
\hline es51 & Cataluña & 69.4 & 22.5 & 4 \\
\hline es52 & Comunidad Valenciana & 71.6 & 13.1 & 4 \\
\hline es53 & Illes Balears & 30.5 & 11.7 & 4 \\
\hline es61 & Andalucia & 40.7 & 10.2 & 4 \\
\hline es62 & Murcia & 50.2 & 10.3 & 4 \\
\hline es63 & Ceuta & 216.4 & 12.2 & 2 \\
\hline es64 & Melilla & 418.7 & 11.9 & 2 \\
\hline es70 & Canarias (ES) & 49.7 & 8.8 & 4 \\
\hline fi13 & Itä-Suomi & 70.4 & 24.3 & 4 \\
\hline fi18 & Etelä-Suomi & 155.6 & 45.7 & 1 \\
\hline fi19 & Länsi-Suomi & 90.5 & 36.8 & 3 \\
\hline fi1a & Pohjois-Suomi & 91.2 & 44.4 & 3 \\
\hline fi20 & Åland & 47.9 & 28.3 & 3 \\
\hline fr10 & Île de France & 238.8 & 46.1 & 1 \\
\hline fr21 & Champagne-Ardenne & 33.7 & 20.6 & 4 \\
\hline fr22 & Picardie & 28.9 & 22.2 & 4 \\
\hline fr23 & Haute-Normandie & 68.9 & 24.3 & 4 \\
\hline fr24 & Centre & 60.2 & 25.4 & 3 \\
\hline fr25 & Basse-Normandie & 100.2 & 18.7 & 2 \\
\hline fr26 & Bourgogne & 39.5 & 20.2 & 4 \\
\hline fr30 & Nord - Pas-de-Calais & 65.7 & 21.0 & 4 \\
\hline fr41 & Lorraine & 102.1 & 24.1 & 2 \\
\hline fr42 & Alsace & 196.6 & 30.7 & 1 \\
\hline fr43 & Franche-Comté & 131.4 & 32.6 & 1 \\
\hline fr51 & Pays de la Loire & 76.8 & 22.2 & 4 \\
\hline fr52 & Bretagne & 78.6 & 25.1 & 3 \\
\hline fr53 & Poitou-Charentes & 55.4 & 17.1 & 4 \\
\hline fr61 & Aquitaine & 58.9 & 23.1 & 4 \\
\hline fr62 & Midi-Pyrénées & 89.5 & 34.7 & 3 \\
\hline fr63 & Limousin & 53.5 & 19.7 & 4 \\
\hline fr71 & Rhône-Alpes & 55.7 & 32.3 & 3 \\
\hline fr72 & Auvergne & 30.3 & 24.3 & 4 \\
\hline fr81 & Languedoc-Roussillon & 35.0 & 24.9 & 3 \\
\hline fr82 & Provence-Alpes-Côte d'Azur & 66.1 & 26.7 & 3 \\
\hline fr83 & Corse & 7.8 & 19.7 & 4 \\
\hline gr11 & Anatoliki Makedonia, Thraki & 13.4 & 6.1 & 4 \\
\hline gr12 & Kentriki Makedonia & 0.7 & 8.0 & 4 \\
\hline gr13 & Dytiki Makedonia & -15.5 & 6.9 & 4 \\
\hline gr14 & Thessalia & 2.3 & 5.4 & 4 \\
\hline gr21 & Ipeiros & 0.8 & 7.6 & 4 \\
\hline gr22 & Ionia Nisia & -1.5 & 9.3 & 4 \\
\hline gr23 & Dytiki Ellada & -7.9 & 7.5 & 4 \\
\hline gr24 & Sterea Ellada & 13.1 & 8.2 & 4 \\
\hline gr25 & Peloponnisos & -24.2 & 6.4 & 4 \\
\hline gr30 & Attiki & 49.4 & 14.6 & 4 \\
\hline gr41 & Voreio Aigaio & 3.4 & 6.9 & 4 \\
\hline gr42 & Notio Aigaio & 1.1 & 7.5 & 4 \\
\hline gr43 & Kriti & 5.6 & 7.7 & 4 \\
\hline hu10 & Közép-Magyarország & 159.6 & 32.4 & 1 \\
\hline hu21 & Közép-Dunántúl & 195.6 & 36.2 & 1 \\
\hline
\end{tabular}




\begin{tabular}{|c|c|c|c|c|}
\hline hu22 & Nyugat-Dunántúl & 169.5 & 37.1 & 1 \\
\hline hu23 & Dél-Dunántúl & 151.8 & 22.7 & 2 \\
\hline hu31 & Észak-Magyarország & 144.1 & 22.5 & 2 \\
\hline hu32 & Észak-Alföld & 240.7 & 19.3 & 2 \\
\hline hu33 & Dél-Alföld & 130.7 & 17.0 & 2 \\
\hline ie01 & Border, Midlands and Western & 55.1 & 32.9 & 3 \\
\hline $\mathrm{ie} 02$ & Southern and Eastern & 164.8 & 42.8 & 1 \\
\hline itc1 & Piemonte & 41.9 & 28.2 & 3 \\
\hline itc2 & Valle d'Aosta & 5.6 & 24.7 & 4 \\
\hline itc3 & Liguria & 37.0 & 21.8 & 4 \\
\hline itc4 & Lombardia & 20.5 & 27.1 & 3 \\
\hline itd1 & Bolzano-Bozen & 22.8 & 17.0 & 4 \\
\hline itd2 & Trento & 50.7 & 21.9 & 4 \\
\hline itd3 & Veneto & 34.8 & 21.5 & 4 \\
\hline itd4 & Friuli-Venezia Giulia & 43.9 & 24.2 & 4 \\
\hline itd5 & Emilia-Romagna & 29.1 & 23.0 & 4 \\
\hline ite1 & Toscana & 25.5 & 19.5 & 4 \\
\hline ite2 & Umbria & 18.5 & 17.4 & 4 \\
\hline ite3 & Marche & 82.4 & 17.1 & 4 \\
\hline ite4 & Lazio & 29.5 & 29.8 & 3 \\
\hline itf1 & Abruzzo & 42.3 & 17.2 & 4 \\
\hline itf2 & Molise & 41.8 & 13.1 & 4 \\
\hline itf3 & Campania & 39.7 & 14.2 & 4 \\
\hline itf4 & Puglia & 23.9 & 10.9 & 4 \\
\hline itf5 & Basilicata & 122.1 & 11.2 & 2 \\
\hline itf6 & Calabria & 14.8 & 10.5 & 4 \\
\hline itg1 & Sicilia & 10.3 & 12.0 & 4 \\
\hline itg2 & Sardegna & 26.7 & 13.0 & 4 \\
\hline lt00 & Lithuania & 126.5 & 17.0 & 2 \\
\hline lu00 & Luxembourg & 382.7 & 41.4 & 1 \\
\hline $\operatorname{lv00}$ & Latvia & 133.1 & 13.7 & 2 \\
\hline $\mathrm{mt} 00$ & Malta & 271.2 & 29.2 & 1 \\
\hline nl11 & Groningen & 22.5 & 34.8 & 3 \\
\hline nl12 & Friesland & 100.4 & 24.8 & 2 \\
\hline nl13 & Drenthe & 133.6 & 26.4 & 1 \\
\hline $\mathrm{nl} 21$ & Overijssel & 39.3 & 31.2 & 3 \\
\hline $\mathrm{nl} 22$ & Gelderland & 91.6 & 35.5 & 3 \\
\hline $\mathrm{nl} 23$ & Flevoland & 86.4 & 44.0 & 3 \\
\hline nl31 & Utrecht & 152.1 & 40.1 & 1 \\
\hline nl32 & Noord-Holland & 201.4 & 33.2 & 1 \\
\hline nl33 & Zuid-Holland & 182.9 & 34.9 & 1 \\
\hline nl34 & Zeeland & 255.6 & 31.7 & 1 \\
\hline nl41 & Noord-Brabant & 58.2 & 47.5 & 3 \\
\hline $\mathrm{nl} 42$ & Limburg & 62.5 & 42.6 & 3 \\
\hline pl11 & Lódzkie & 120.3 & 10.5 & 2 \\
\hline pl12 & Mazowieckie & 127.3 & 18.7 & 2 \\
\hline $\mathrm{pl} 21$ & Malopolskie & 175.2 & 11.8 & 2 \\
\hline $\mathrm{pl} 22$ & Slaskie & 122.5 & 12.0 & 2 \\
\hline pl31 & Lubelskie & 69.6 & 8.0 & 4 \\
\hline pl32 & Podkarpackie & 117.5 & 6.9 & 2 \\
\hline pl33 & Swietokrzyskie & 98.4 & 5.8 & 2 \\
\hline pl34 & Podlaskie & 104.2 & 6.1 & 2 \\
\hline pl41 & Wielkopolskie & 95.5 & 11.8 & 4 \\
\hline pl42 & Zachodniopomorskie & 78.8 & 11.9 & 4 \\
\hline pl43 & Lubuskie & 118.0 & 11.2 & 2 \\
\hline pl51 & Dolnoslaskie & 99.6 & 13.3 & 2 \\
\hline pl52 & Opolskie & 146.4 & 12.1 & 2 \\
\hline pl61 & Kujawsko-Pomorskie & 48.4 & 10.7 & 4 \\
\hline pl62 & Warminsko-Mazurskie & 85.8 & 6.8 & 4 \\
\hline pl63 & Pomorskie & 105.4 & 14.9 & 2 \\
\hline pt11 & Norte & 72.4 & 11.8 & 4 \\
\hline pt15 & Algarve & 74.9 & 11.1 & 4 \\
\hline pt16 & Centro (PT) & 72.7 & 10.3 & 4 \\
\hline pt17 & Lisboa & 189.3 & 19.7 & 2 \\
\hline pt18 & Alentejo & 56.4 & 13.8 & 4 \\
\hline ro11 & Nord-Vest & 50.4 & 9.4 & 4 \\
\hline ro12 & Centru & 51.1 & 8.9 & 4 \\
\hline ro21 & Nord-Est & 21.6 & 6.0 & 4 \\
\hline ro22 & Sud-Est & 28.4 & 6.0 & 4 \\
\hline ro31 & Sud - Muntenia & 19.3 & 7.8 & 4 \\
\hline ro32 & Bucuresti - Ilfov & 488.8 & 21.4 & 2 \\
\hline ro41 & Sud-Vest Oltenia & 29.1 & 8.1 & 4 \\
\hline ro42 & Vest & 14.6 & 12.6 & 4 \\
\hline
\end{tabular}




\begin{tabular}{|c|c|c|c|c|}
\hline se11 & Stockholm & 336.6 & 56.0 & 1 \\
\hline se12 & Östra Mellansverige & 103.2 & 42.7 & 1 \\
\hline se21 & Småland med öarna & 84.9 & 25.4 & 3 \\
\hline se22 & Sydsverige & 107.7 & 44.2 & 1 \\
\hline se23 & Västsverige & 106.3 & 46.3 & 1 \\
\hline se31 & Norra Mellansverige & 85.6 & 30.6 & 3 \\
\hline se32 & Mellersta Norrland & 120.4 & 31.0 & 1 \\
\hline se33 & Övre Norrland & 59.1 & 32.6 & 3 \\
\hline si00 & Slovenia & 72.0 & 25.9 & 3 \\
\hline sk01 & Bratislavský kraj & 862.2 & 40.4 & 1 \\
\hline sk02 & Západné Slovensko & 92.6 & 27.1 & 3 \\
\hline sk03 & Stredné Slovensko & 143.4 & 24.5 & 2 \\
\hline sk04 & Východné Slovensko & 165.7 & 19.1 & 2 \\
\hline ukc1 & Tees Valley and Durham & 151.0 & 21.1 & 2 \\
\hline ukc2 & Northumberland, Tyne and Wear & 104.2 & 22.6 & 2 \\
\hline ukd1 & Cumbria & 34.4 & 21.8 & 4 \\
\hline ukd2 & Cheshire & 118.5 & 42.7 & 1 \\
\hline ukd3 & Greater Manchester & 65.4 & 23.9 & 4 \\
\hline ukd4 & Lancashire & 162.0 & 28.8 & 1 \\
\hline ukd5 & Merseyside & 107.7 & 22.6 & 2 \\
\hline uke1 & East Yorkshire and Northern Lincolnshire & 73.5 & 17.4 & 4 \\
\hline uke2 & North Yorkshire & 36.0 & 24.5 & 4 \\
\hline uke3 & South Yorkshire & 80.7 & 21.3 & 4 \\
\hline uke4 & West Yorkshire & 53.0 & 21.8 & 4 \\
\hline ukf1 & Derbyshire and Nottinghamshire & 121.6 & 27.7 & 1 \\
\hline ukf2 & Leicestershire, Rutland and Northants & 70.7 & 29.4 & 3 \\
\hline ukf3 & Lincolnshire & 21.9 & 17.7 & 4 \\
\hline ukg1 & Herefordshire, Worcestershire and Warks & 123.3 & 26.8 & 1 \\
\hline ukg2 & Shropshire and Staffordshire & 99.7 & 22.2 & 2 \\
\hline ukg3 & West Midlands & 257.6 & 26.3 & 1 \\
\hline ukh1 & East Anglia & 68.6 & 42.6 & 3 \\
\hline ukh2 & Bedfordshire, Hertfordshire & 86.2 & 44.8 & 3 \\
\hline ukh3 & Essex & 99.9 & 35.0 & 1 \\
\hline uki1 & Inner London & 83.1 & 42.0 & 3 \\
\hline uki2 & Outer London & 85.6 & 27.9 & 3 \\
\hline ukj1 & Berkshire, Bucks and Oxfordshire & 90.3 & 52.8 & 3 \\
\hline ukj2 & Surrey, East and West Sussex & 61.6 & 32.6 & 3 \\
\hline ukj3 & Hampshire and Isle of Wight & 136.7 & 43.5 & 1 \\
\hline ukj4 & Kent & 111.5 & 29.1 & 1 \\
\hline ukk1 & Gloucestershire, Wiltshire and Bristol/Bath area & 205.7 & 38.7 & 1 \\
\hline ukk2 & Dorset and Somerset & 113.2 & 20.8 & 2 \\
\hline ukk3 & Cornwall and Isles of Scilly & 59.0 & 19.6 & 4 \\
\hline ukk4 & Devon & 72.7 & 22.1 & 4 \\
\hline ukl1 & West Wales and The Valleys & 39.6 & 18.8 & 4 \\
\hline ukl2 & East Wales & 71.6 & 28.4 & 3 \\
\hline ukm2 & Eastern Scotland & 49.2 & 26.9 & 3 \\
\hline ukm3 & South Western Scotland & 118.2 & 27.0 & 1 \\
\hline ukm5 & North Eastern Scotland & 81.2 & 32.5 & 3 \\
\hline ukm6 & Highlands and Islands & 8.0 & 23.2 & 4 \\
\hline ukn0 & Northern Ireland & 99.3 & 19.9 & 2 \\
\hline
\end{tabular}

Notes: The Performance Index (PI) is defined by the expression: $P I=\frac{\left(F D I_{i} / \sum_{i} F D I_{i}\right)}{\left(G D P_{i} / \sum_{i} G D P_{i}\right)} 100$.

Regarding the Potential Index we have constructed, drawing from UNCTAD (2002), our own Index for the EU regions by using the following variables: per capita GDP, R\&D expenditures as percentage of GDP, exports plus imports as percentage of GDP, and the percentage of employment in high technology sectors. The index for a region $i$ is computed as the simple average of the scores on the chosen variables for that region. The score (S) for each variable is computed as: $S=\left[\frac{\left(V_{i}-V_{\min }\right)}{\left(V_{\max }-V_{\min }\right)}\right] 100$, where $V_{i}$ refers to the value of the variable for region $i$ and $V_{\min }$ and $V_{\max }$ refer, respectively, to the lowest and highest values of the variable among the regions.

As for the classification, 1 denotes front-runners, 2 denotes above-potential economies, 3 represents below-potential economies, and 4 denotes under-performers. 